\title{
The petroleum system: a new classification scheme based on reservoir qualities
}

\author{
Jing-Zhou Zhao, ${ }^{1,2} \cdot$ Jun $\mathrm{Li}^{1,2} \cdot$ Wei-Tao $\mathrm{Wu}^{1,2} \cdot$ Qing $\mathrm{Cao}^{1,2} \cdot \mathrm{Yu}^{\mathrm{B}}$-Bin Bai ${ }^{1,2} \cdot$ Chuang $\mathrm{Er}^{1,2}$
}

Received: 7 February 2018/Published online: 13 December 2018

(C) The Author(s) 2018

\begin{abstract}
A new classification of petroleum systems (PSs) based on reservoir qualities is proposed. We classify PSs into the following three basic types: (1) source-rock petroleum system (SPS); (2) tight-reservoir or tight petroleum system (TPS); and (3) conventional-reservoir or conventional petroleum system (CPS). The CPS is a PS in which hydrocarbons accumulate in conventional reservoirs, and all the essential elements and processes are significant and indispensable. Oil and gas accumulations are geographically discrete and therefore exist as discontinuous accumulations. The TPS is a PS where hydrocarbons accumulate in tight reservoirs and the source rock, reservoir, seal, migration, and trap are also indispensable, but the traps are mostly non-anticlinal and the accumulations are primarily quasi-continuous and secondarily discontinuous. The SPS is a PS where both hydrocarbon generation and accumulation occurred in source rocks and traps and migration are unnecessary or inconsequential; the hydrocarbon distribution is extensive and continuous and has no distinct boundaries. The aforementioned three PSs can be derived from a common hydrocarbon source kitchen and are closely linked in terms of their formation and distribution. Therefore, to maximize the exploration efficiency, a comprehensive study and different strategies are needed by considering the SPS, TPS, and CPS as parts of a greater whole.
\end{abstract}

Keywords Petroleum system - Classification - Conventional petroleum system · Unconventional petroleum system · Source-rock petroleum system $\cdot$ Tight petroleum system

\section{Introduction}

Since the notion of the PS was introduced in the 1970s, studies on the PS have mainly focused on the research and exploration of conventional oil and gas accumulations. On this basis, it was proposed that a PS consists of such essential elements as source rock, reservoir, seal, and overburden rocks, and such processes as petroleum generation, migration, accumulation, and entrapment (Magoon and Dow 1994). The concept of the "total petroleum system" advanced later by Magoon and Schmoker (2000) also

Edited by Jie Hao

Jing-Zhou Zhao

jzzhao@xsyu.edu.cn

1 School of Earth Sciences and Engineering, Xi' an Shiyou University, Xi' an 710065, Shaanxi, China

2 Shaanxi Key Laboratory of Petroleum Accumulation Geology, Xi'an Shiyou University, Xi' an 710065, Shaanxi, China emphasized the necessity of the aforementioned elements and processes. The difference from the widely accepted PS concept is that the "total petroleum system" includes not only the discovered oil and gas seepages, shows, and reservoirs, but the undiscovered hydrocarbons as well, and the hydrocarbon source can be either one or more active pods of source rocks (Magoon and Schmoker 2000). Furthermore, Magoon and Schmoker (2000) noted that the "total petroleum system" concept presumes that migration pathways exist, either at present or in the past, to connect the source with the accumulations. In addition, similar to the nomenclature of the PS, as proposed by Magoon and Dow (1994), the "total petroleum system" is also named after the stratigraphic names of the source rock plus the reservoir. Thus, it can be seen that in both traditional and the "total petroleum system," source rock and reservoir are regarded as two separate rock units, and the necessity and importance of migration to petroleum accumulation is highlighted.

However, the increasing discovery of and the in-depth research into unconventional oil and gas accumulations in recent years has indicated that the traditional PS theories 
and practices established on the basis of conventional petroleum accumulation studies seem to have become unable to completely satisfy the needs of current hydrocarbon exploration and development. For example, source rocks and reservoirs are commonly regarded as two distinct stratigraphic units in the general practice of traditional PS studies and exploration. Nevertheless, they correspond to a common stratigraphic unit in some unconventional petroleum accumulations, such as those of shale oil and gas and coalbed methane (CBM), where the unit acts not only as a source rock but also as a reservoir. Furthermore, in the studies of traditional PS, traps are underlined as an indispensable element in petroleum accumulation, but are usually unnecessary or even completely ineffective in the formation of shale oil and gas and many CBM accumulations, although seals are still necessary. In addition, migration is less important for many unconventional petroleum accumulations than it is for conventional petroleum accumulations, and even the driving force, and migrating pattern, pathway, and distance are quite different from those of conventional petroleum accumulation (Zhao et al. 2016a). On the other hand, studies have indicated that a hydrocarbon source kitchen can lead to both conventional and unconventional petroleum accumulations and that they can coexist in a basin and are closely related to each other in the formation and distribution, but cannibalize each other in terms of resource potential (Zhao et al. 2016a). It follows that the studies of PS ought to shift from the traditional, conventional accumulation dominated thinking toward a new paradigm that is compatible with both conventional and unconventional accumulations. Because the focus of petroleum exploration is switching from conventional to unconventional resources, the PS studies need to adjust accordingly. Therefore, comprehensive studies of the major characteristics, mutual relationships, and the formation and distribution rules of conventional and unconventional PSs have become necessary for petroleum exploration.

\section{Classification of petroleum systems and their characteristics}

A variety of opinions have been put forward with respect to the classification of PSs. Among them, Magoon (1989) classified PSs of the USA based on the complexity of the overlying rock (purebred versus hybrid), reservoir lithology (siliciclastic versus carbonate), and kerogen type (I, II, and III). Demaison and Huizinga's (1991) division was based on the features of hydrocarbon charging, migration, and entrapment. Magoon and Dow (1994) classified PSs into single-sourced and multiple-sourced systems in terms of the number of source kitchens. Considering the coexistence of multiple source kitchens in many superimposed basins and the resultant complexity of hydrocarbon migration and accumulation, Zhao and He (2000) introduced the concept of "composite petroleum system" and discussed the classification of it. In addition, a PS can be subdivided into different petroleum migration-accumulation systems in terms of the migration and accumulation characteristics (Zhao and Al-aasm 2012).

Nevertheless, a PS classification based on reservoir qualities has not been discussed in previous studies on PS classification, and almost all the PS classifications are based on the accumulations in conventional reservoirs. In fact, the quality of reservoirs plays a key role in affecting hydrocarbon charge, migration, and accumulation; reservoirs of different qualities generally have different characteristics of hydrocarbon migration and accumulation (Zhao et al. 2016a). As a result, in this article, we base our classification of PSs on reservoir qualities, in combination with the corresponding characteristics of hydrocarbon migration and accumulation, and divide them into the following three basic types: source-rock PS (SPS), tightreservoir PS or tight PS (TPS), and conventional-reservoir PS or conventional PS (CPS). The SPS, TPS, and CPS are dominated and characterized by continuous, quasi-continuous, and discontinuous accumulations, respectively (Fig. 1). Tables 1 and 2 show the major characteristics of the three PSs and some typical examples of conventional, tight, and source-rock reservoirs, respectively.

It should be noted that the PS classification scheme proposed in this article is not a substitute for the traditional proposals on PS classification, but a supplement to them. In addition, this is a generalized classification of PSs. Therefore, although different reservoirs with similar qualities can be attributed to the same category of PS in our classification, they were identified, according to Magoon and Dow (1994), as different PSs in specific practices of PS identification in a basin.

\subsection{Source-rock petroleum system (SPS)}

This petroleum system, formed within source rocks, is a self-sourcing and self-storing PS. In terms of the lithological types of source rocks, the SPS includes shale SPS, carbonate SPS, and coal SPS. Typical representatives include shale oil/gas and CBM systems. The major characteristics of the SPS are as follows:

\section{(1) Phase States of Hydrocarbons}

Unlike hydrocarbons stored mostly as free oil and gas in non-source-rock reservoirs, hydrocarbons accumulated in source-rock reservoirs can be in a free state, an absorbed/ adsorbed state, or even a dissolved state. This is particularly true for natural gas storage, while oil is stored 


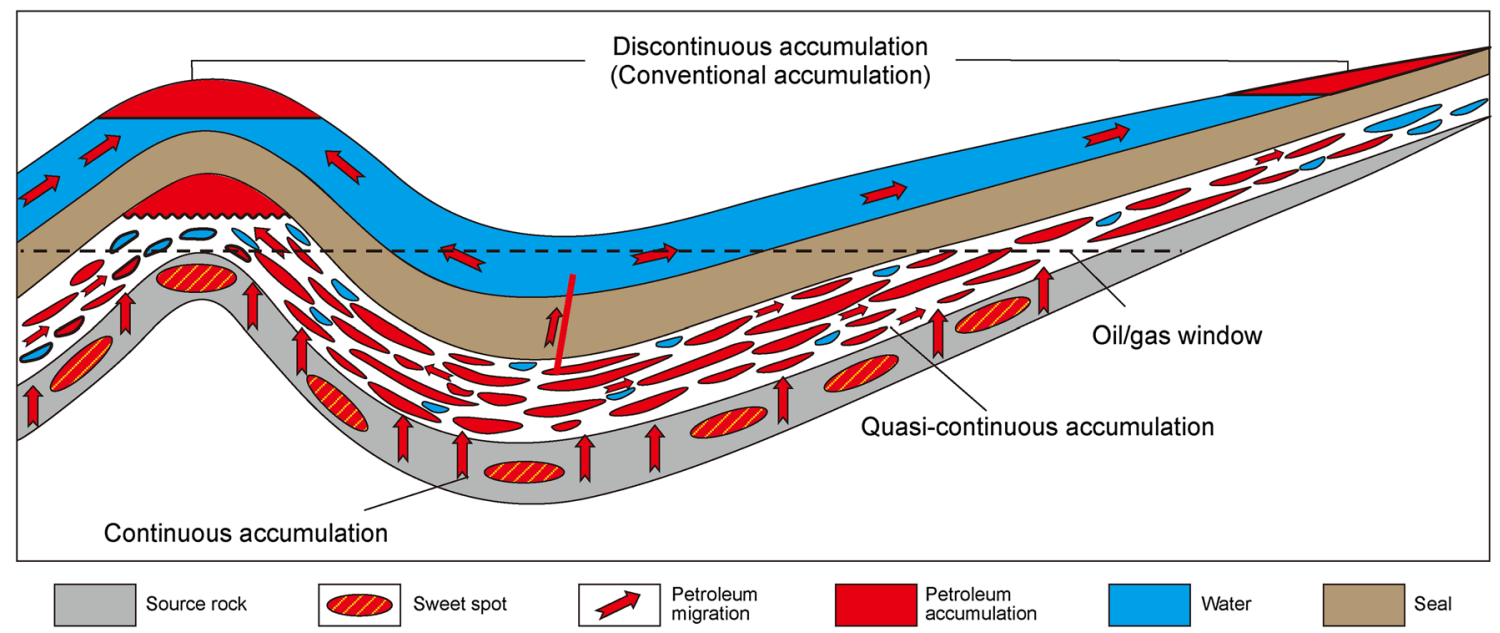

Fig. 1 Distribution of continuous, quasi-continuous, and discontinuous petroleum accumulations in a petroleum basin, showing they typically occur in source rocks (gray), tight reservoirs, and conventional reservoirs, respectively

Table 1 Comparison of the source petroleum system, tight petroleum system, and conventional petroleum system

\begin{tabular}{|c|c|c|c|}
\hline Types of petroleum systems & Source petroleum system & Tight petroleum system & Conventional petroleum system \\
\hline \multicolumn{4}{|l|}{ Essential elements } \\
\hline Source rocks & Shales, carbonates, coals & Shales, carbonates, coals & Shales, carbonates, coals \\
\hline Reservoirs & Source rocks & Tight sandstones and carbonates & Conventional reservoirs \\
\hline Seals & Self-sealing & $\begin{array}{l}\text { Self-sealing; mudstones, } \\
\text { carbonates, etc. }\end{array}$ & Mudstones, carbonates, etc. \\
\hline Traps & Not required & $\begin{array}{l}\text { Non-anticlinal traps are necessary, } \\
\text { while anticlinal trap functions for } \\
\text { some }\end{array}$ & Indispensable \\
\hline \multicolumn{4}{|l|}{ Essential processes } \\
\hline Generation & No particular requirement for timing & After the reservoir gets tight & $\begin{array}{l}\text { Prior to or contemporaneous with } \\
\text { trap formation }\end{array}$ \\
\hline Migration & Insignificant or over short distances & $\begin{array}{l}\text { Primary migration is important, } \\
\text { and secondary migration is } \\
\text { mostly over short distance. } \\
\text { Migration is mainly } \\
\text { overpressure-driven flow }\end{array}$ & $\begin{array}{l}\text { Both primary and secondary } \\
\text { migrations are significant. And } \\
\text { secondary migration is } \\
\text { commonly buoyancy-driven flow } \\
\text { and sometimes overpressure- } \\
\text { driven flow }\end{array}$ \\
\hline Accumulation & Mostly continuous & Quasi-continuous or discontinuous & Discontinuous \\
\hline Preservation & Commonly excellent & Moderate to excellent & Critical \\
\hline Types of accumulation & Mostly continuous & $\begin{array}{l}\text { Primarily quasi-continuous, and } \\
\text { secondarily discontinuous }\end{array}$ & Discontinuous \\
\hline Typical accumulation & Shale oil and gas & Tight oil and gas & Conventional reservoirs \\
\hline
\end{tabular}

primarily in a free state. In reality, the existence of more absorbed/adsorbed hydrocarbons is one of the most distinctive features of the SPS. For instance, CBM occurs mainly in an absorbed/adsorbed state. For shale gas, the free, absorbed/adsorbed and dissolved states are significant, but the ratio among them is variable (Curtis 2002; Wang and Sheng 2017). According to Jarvie (2012), the proportion of absorbed/adsorbed gas in the major shale gas accumulations of North America is $10 \%-70 \%$, and that of free gas accounts for $30 \%-90 \%$. Indeed, it is the existence of absorbed/adsorbed gas that enables oil/gas accumulations inside source rocks to have typical characteristics of continuous accumulations, while a relatively higher proportion of free-state hydrocarbons are more favorable for the high yield of oil and gas.

\section{(2) Reservoirs}

One of the most prominent attributes of the SPS's reservoirs is that they are tight (microdarcies) to ultra-tight (nanodarcies). However, there are also reservoirs with 
Table 2 Some typical examples of conventional, tight, and shale reservoirs

\begin{tabular}{|c|c|c|c|c|c|c|}
\hline $\begin{array}{l}\text { Reservoir } \\
\text { type }\end{array}$ & $\begin{array}{l}\text { Basin or } \\
\text { oil/gas field }\end{array}$ & Formation & Lithology & $\begin{array}{l}\text { Porosity }(\%) \text { range/ } \\
\text { average }\end{array}$ & $\begin{array}{l}\text { Permeability (md) } \\
\text { range/average }\end{array}$ & Source \\
\hline \multicolumn{7}{|c|}{ Conventional reservoirs } \\
\hline \multicolumn{2}{|c|}{$\begin{array}{l}\text { Penglai-193 oilfield } \\
\text { (China) }\end{array}$} & $\begin{array}{l}\text { Minghuazhen Fm. and } \\
\text { Guantao Fm. }\left(\mathrm{N}_{1}\right)\end{array}$ & Sandstones & $<37 / 27$ & $<30,000 / 750$ & Halbouty (2003) \\
\hline \multicolumn{2}{|c|}{ Masila oilfield (Yemen) } & Upper Qishn Fm. $\left(\mathrm{K}_{1}\right)$ & Sandstones & $15-28 / 20$ & $<10,000 / 1500$ & Halbouty (2003) \\
\hline \multicolumn{2}{|c|}{$\begin{array}{l}\text { Panphandle-Hugoto gas } \\
\text { Field (USA) }\end{array}$} & Wolfcamp Fm. $\left(\mathrm{P}_{1}\right)$ & Dolomites & $16-30$ & $1-5$ & Zhang (1990) \\
\hline \multicolumn{2}{|c|}{ Urengoy (Russia) } & $\mathrm{K}_{1}-\mathrm{K}_{2}$ & Sandstones & $13-27$ & $8-495$ & Zhang (1990) \\
\hline \multicolumn{7}{|c|}{ Tight reservoirs } \\
\hline \multicolumn{2}{|c|}{ Ordos Basin (China) } & Yanchang Fm. $\left(\mathrm{T}_{3}\right)$ & Sandstones & $2-12$ & $0.01-1$ & Zhao et al. (2012b) \\
\hline \multicolumn{2}{|c|}{ Sulige gas field (China) } & $\begin{array}{l}\text { Xiashihezi Fm. and Shanxi } \\
\text { Fm. }\left(\mathrm{P}_{2}\right)\end{array}$ & Sandstones & $5.0-21.8 / 10.3$ & $0.1-1.0 / 0.38$ & Zhao et al. (2012a) \\
\hline \multicolumn{2}{|c|}{ Hechuan gas field (China) } & Xujiahe Fm. $\left(\mathrm{T}_{3}\right)$ & Sandstones & $8-9 / 8.5$ & $0.2-0.4 / 0.3$ & Li et al. (2013a) \\
\hline \multicolumn{2}{|c|}{ Piceance Basin (USA) } & Mesaverde group $\left(\mathrm{K}_{2}\right)$ & Sandstones & $2-10$ & $0.0001-0.1$ & $\begin{array}{l}\text { Hood and } \\
\quad \text { Yurewicz (2008) }\end{array}$ \\
\hline \multicolumn{7}{|c|}{ Source-rock reservoirs } \\
\hline \multicolumn{2}{|c|}{ Sichuan Basin (China) } & $\begin{array}{l}\text { Wufeng Fm. }\left(\mathrm{O}_{3}\right) \text {. and } \\
\text { Longmaxi Fm. }\left(\mathrm{S}_{1}\right)\end{array}$ & Shale & $4.2-6.2$ & $0.000042-0.000348$ & Dong et al. (2016) \\
\hline \multicolumn{2}{|c|}{ Appalachian Basin (USA) } & Marcellus shale $\left(D_{2}\right)$ & Shale & $4.0-12.0 / 6.2$ & $0-0.00007 / 0.00002$ & Jarvie (2012) \\
\hline \multicolumn{2}{|c|}{ Fort Worth Basin (USA) } & Barnett shale $\left(\mathrm{C}_{1}\right)$ & Shale & $4.0-6.0 / 5.0$ & $0-0.0001 / 0.00005$ & Jarvie (2012) \\
\hline
\end{tabular}

higher permeabilities. As reservoirs of continuous accumulations, source rocks, no matter if they are shales, carbonates, or coals, belong to the most inferior type of reservoirs for hydrocarbon accumulation. Their matrix permeability generally ranges from a few nanodarcies (nd) to a few millidarcies (md). Among the various source-rock reservoirs, shales are commonly the tightest. According to Curtis (2002) and Jarvie (2012), the permeabilities of major North America shale gas reservoirs are in the range of 0-5000 nd, with average values ranging from 10-1000 nd, while the porosity is in the range of $1 \%-14 \%$, with average values of 4\%-8\% (Jarvie 2012). Nevertheless, the permeability of CBM reservoirs is highly variable due to the development of cleats and fractures to some degree. Despite this, the matrix permeabilities of coals are commonly quite low, and, hence, many CBM accumulations can be attributed to the continuous type. In general, the permeability of high-ranked coals is the lowest, followed by medium-ranked coals. For example, the high-ranked Carboniferous-Permian coals from the southern Qinshui Basin have an effective porosity of $1.1 \%-7.7 \%$ (generally $<5 \%$ ) and a permeability of $0.1-6.7$ md (usually $<2$ md) (Lin and $\mathrm{Su}$ 2007). However, the Cretaceous Fruitland Formation coals in the San Juan Basin are medium-ranked, with permeabilities mainly in the range of 5-60 md in gasproducing areas (Ayers Jr 2002). The coals in the Black Warrior Basin are mostly low-ranked (bituminous) and have a permeability of 1-25 md (Jenkins and Boyer II 2008).

It is because of the poor reservoir qualities and the small and variable pore throats that make it nearly impossible for hydrocarbons in source rocks to migrate over long distances and to accumulate in a concentrated area. Instead, hydrocarbons in such reservoirs tend to form a widespread and continuous distribution. On the contrary, if source-rock reservoirs were similar to conventional reservoirs with high porosities and permeabilities, discontinuous or conventional trap-controlled accumulations rather than continuous accumulations would tend to occur in them. Some coal reservoirs, particularly coals of low to medium rank, are quite similar to conventional reservoirs. The permeabilities of low-ranked coals in the Powder River Basin are, for instance, usually between $10 \mathrm{md}$ and a few darcies (Ayers 2002). The Walloon Formation coals in the Australian Surat Basin are lignite, belonging to typically low-ranked CBM reservoirs, and have relatively good qualities, with an average porosity of approximately $17 \%$ and a permeability of roughly 1-300 md. The Blackwater Group coals in the Northern Bowen Basin are at a low metamorphic rank, and their porosities are 6\%-13\%, while their permeabilities are 5-30 md (Li et al. 2014).

As far as the factors controlling the qualities of sourcerock reservoirs are concerned, the organic matter features (content, type and maturity), mineral composition, compaction and diagenesis, and structural deformation 
(fractures) are among the most significant. The total organic matter (TOC) content has remarkable effects on pore development in organic-rich shales. According to Milliken et al. (2013) regarding the relationship between the porosity and TOC of the Devonian Marcellus shales in Pennsylvania (Fig. 2a), the shale porosity is positively correlated with TOC when TOC $<5.5 \%$, but does not increase when $\mathrm{TOC}>5.5 \%$. In contrast, the porosity remains basically unchanged or even slightly decreases, which has been interpreted as a potential result of the "collapse" of pores caused by hydrocarbon expulsion. Nevertheless, studies on the Chang-7 lacustrine shales of the Yanchang Formation in the Ordos Basin have shown that pore volumes are negatively correlated to TOC (Fig. 2b), which is similar to the case noted by Jarvie (2011) for the Doig shales. This is probably due to the fact that the maturities of Chang-7 shales $\left(R_{\mathrm{o}} \sim 0.7 \%-1.2 \%\right)$ are not high enough, and, hence, the pore development is affected primarily by compaction. Based on a study on the New Albany Shale by Mastalerz et al. (2013), the relationship between its total pore volume and $R_{\mathrm{o}}$ differs significantly and is affected by the stage of thermal evolution. Figure $3 \mathrm{a}$ shows that the total pore volume and $R_{\mathrm{o}}$ are negatively correlated when the organic matter is at the immature to mature stage, resembling the Chang-7 lacustrine shale of the Ordos Basin (Fig. 3b). However, when the organic matter has achieved high maturity, the relationship between them becomes positive. This is particularly true for the porosities of organic matter, as they are related to thermal maturation of organic matter and are the result of hydrocarbon generation (Loucks et al. 2009). For instance, organic porosity of the Woodford Shale was observed to be absent in samples with vitrinite reflectance values of up to $0.90 \%$, while the first appearance of secondary pores is observed with the $1.23 \% R_{\mathrm{o}}$ sample (Curtis et al. 2012).

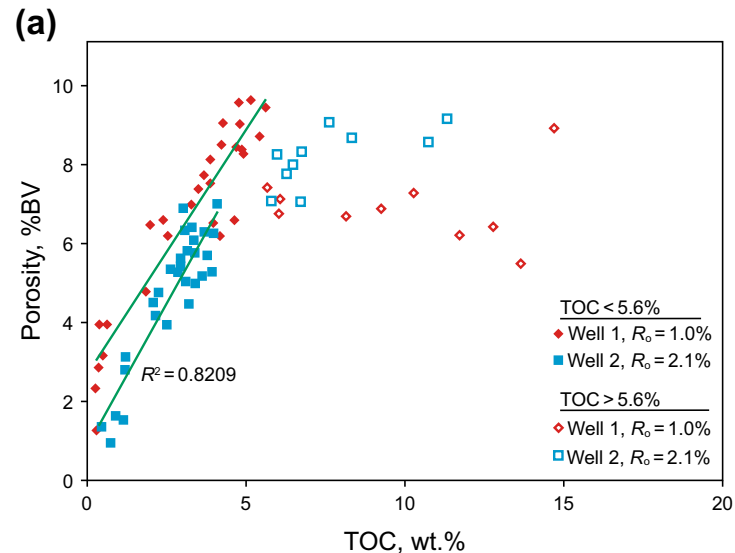

The major cause is that compaction is predominant in early burial stages of shales and pore volumes thus decrease with the increase in $R_{\mathrm{o}}$ during a compactiondominated stage. However, pore volumes increase gradually with $R_{\mathrm{O}}$ in later stages due to the effect of hydrocarbon generation and the resultant increase in organic matter pores (Mastalerz et al. 2013).

\section{(3) Accumulations and Traps}

In the SPS, hydrocarbon accumulations are predominately the continuous type because they occurred in effective source rocks, in which hydrocarbons are thought to be ubiquitous, albeit in varying abundances. The concept of "continuous accumulation" was first introduced in the mid-1990s by Schmoker (1995) to characterize hydrocarbon accumulations with extensive spatial distribution and no defined boundaries that are more or less independent of a water column. Schmoker (1995, 2002) contended that continuous accumulations belong to unconventional hydrocarbon resources and attributed CBM, basin-centered gas, tight gas, shale gas, and natural gas hydrate to this category. According to Zhao et al. (2016a), however, a genuine continuous accumulation probably only occurs within a source rock interval, which is typically represented by shale gas and CBM. Nevertheless, not all shale oil and gas accumulations and CBM accumulations are continuous; in reality, some of them could possibly be discontinuous accumulations if structural elements become dominant controlling factors for hydrocarbon accumulation.

A significant feature of continuous accumulations is that each of them consists of only a single oil or gas reservoir, and, hence, an oil or gas field of continuous accumulation should be non-compartmentalized. Moreover, their spatial distribution is extensive and the reserve scales are generally quite large (Schmoker 1995, 2002), such that the

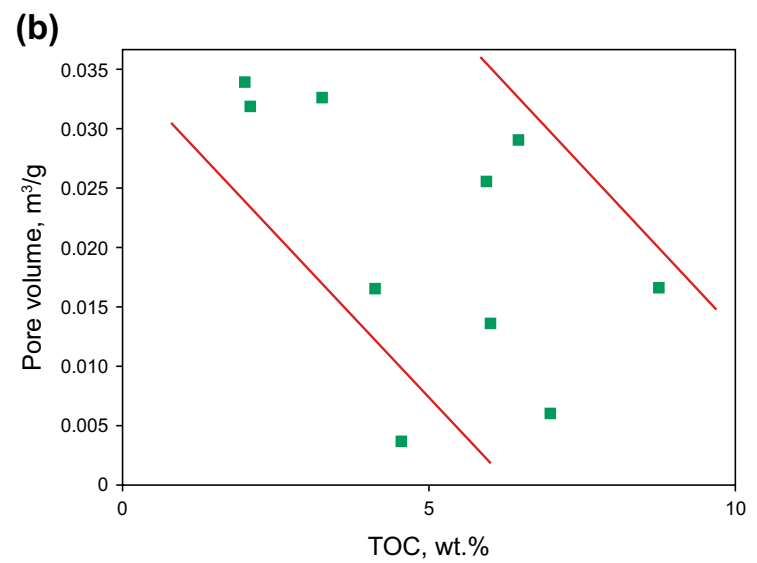

Fig. 2 Relationship between shale porosity and total organic carbon content. a Devonian Marcellus shales from Pennsylvania (Milliken et al. 2013). b Triassic Chang-7 shales from the Ordos Basin (Zhao et al. 2016b), in which the parallel double lines are trend lines 


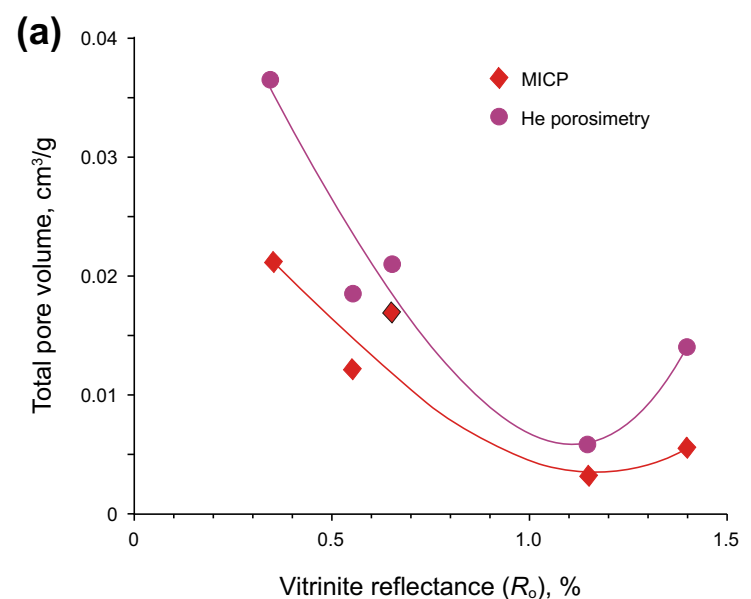

Fig. 3 Illustration of pore volume or Langmuir volume variation with vitrinite reflectance. a The relationship between $R_{\mathrm{o}}$ and pore volume of the New Albany shales (Mastalerz et al. 2013), showing the evolution of pore volume decreasing with $R_{\mathrm{O}}$ if $R_{\mathrm{O}}<1.15 \%$, and increasing with $R_{\mathrm{O}}$ if $R_{\mathrm{O}}>1.15 \%$. (MICP is mercury injection

resultant oil and gas fields can commonly attain giant or even supergiant sizes in terms of resources scales (see Tables 3,4). Field areas are usually thousands, tens of thousands, and even up to hundreds of thousands of square kilometers. As accumulations in source rocks, the distribution area of effective source rocks is also the potential area for hydrocarbon accumulation, but a commercial accumulation in a source rock is commonly determined by sweet spots, which are dependent on the presence of many other factors and will be discussed later.

Secondly, hydrocarbons in continuous accumulations are continuously distributed, implying that hydrocarbons are ubiquitous in the entire areal extent of an accumulation, and neither dry holes nor dry beds would be encountered when such a reservoir is drilled, although variation of hydrocarbon abundances and production rates is commonly remarkable across the extent of the accumulation. Moreover, continuous accumulations also have no explicit boundaries, oil/gas water contact, or edge water or bottom water.

In addition to continuous accumulations, discontinuous accumulations can also occur in source-rock reservoirs, if their permeabilities are high enough. This is relatively more common in CBM reservoirs because the permeability of coals is highly variable, ranging from less than $1 \mathrm{md}$ to more than 1000 md. Generally, the permeability of lowranked coals is higher and almost comparable to that of conventional reservoirs. Thus, accumulations in such permeable coals could often be governed by structural traps and more concentrated at high structural positions. The variation in the permeability of medium-ranked coals is also fairly large, and thereby both continuous and discontinuous accumulations are possible.

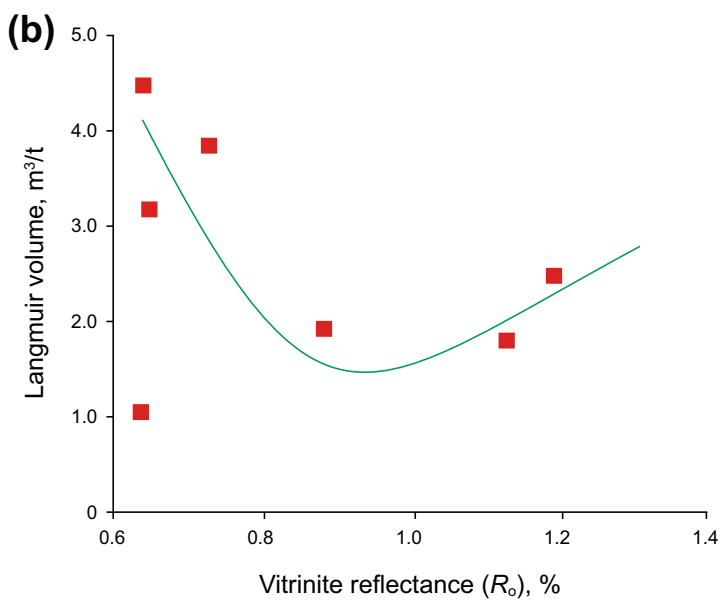

capillary pressure). b The relationship between $R_{\mathrm{o}}$ and the Langmuir volume of the Triassic Chang-7 shales from the Ordos Basin (Zhao et al. 2016b) indirectly indicates a similar evolutionary trend in porosity, but the inflexion point is at about $0.9 \% R_{\mathrm{o}}$

As far as the roles of traps are concerned, studies of the characteristics of continuous accumulations in source rocks indicate that they are essentially not confined by traps. Instead, they are largely controlled by the distribution of effective source rocks, the quality of top and bottom seals, and other factors. Despite this, the existence of structural traps often has certain and even significant effects on the enrichment of a continuous accumulation. In that case, the function of a structural trap is similar to the role of a sweet spot. For source-rock reservoirs with medium to high permeabilities, the accumulations are influenced by traps to some degree and thus might take the shape of a discontinuous type.

\section{(4) Migration}

Continuous accumulations, as redefined by Zhao et al. (2016a), are those that occur within source rocks. In our opinion, continuous accumulation can only form within a source rock. Such types of oil/gas accumulations caused within source rocks mainly occur in situ or are close to where the hydrocarbons are generated, and usually neither significant migration nor a dominant migration pathway is needed. Otherwise, if dominant migration pathways are developed inside source rocks, then oil/gas accumulations therein will probably be subject to conventional traps (such as fractured oil/gas accumulations in mudstones), and more hydrocarbons generated in the source rocks can be expelled and migrate outward. It should be noted that some conventional accumulations, notwithstanding the large areal and "continuous" distribution they may have, possess edge water or bottom water and distinct boundaries in general, which is a diagnostic feature of discontinuous (conventional) accumulations. 
Table 3 Technically recoverable resources (TRR) of some major shale gas plays

\begin{tabular}{|c|c|c|c|c|c|c|}
\hline \multirow[t]{2}{*}{ Location } & \multirow[t]{2}{*}{ Shale play } & \multicolumn{2}{|l|}{ Area } & \multicolumn{2}{|l|}{ TRR } & \multirow[t]{2}{*}{ Source } \\
\hline & & $\mathrm{mi}^{2}$ & $\mathrm{~km}^{2}$ & TCF & TCM & \\
\hline Appalachia & Marcellus & 94,893 & 245,773 & 410.34 & 11.61 & EIA (2011) \\
\hline Sichuan Basin & Longmaxi and Qiongzhusi & & & 93.29 & 2.64 & Dong et al. (2014) \\
\hline U.S. Gulf Coast & Haynesville & 20,584 & 53,313 & 74.71 & 2.11 & Paxton et al. (2017) \\
\hline Bend Arch-Fort Worth Basin & Barnett & & & 53 & 1.50 & Marra et al. (2015) \\
\hline U.S. Gulf Coast Region & Eagle Ford & & & 51.93 & 1.47 & Dubiel et al. (2012) \\
\hline Arkoma Basin & Fayetteville & 9000 & 23,310 & 31.96 & 0.90 & EIA (2011) \\
\hline Arkoma and Ardmore Basins & Woodford & 4700 & 12,173 & 22.21 & 0.63 & EIA (2011) \\
\hline Michigan Basin & Antrim & 12,000 & 31,080 & 19.93 & 0.56 & EIA (2011) \\
\hline
\end{tabular}

$\mathrm{mi}^{2}$, square miles; $\mathrm{km}^{2}$, square kilometers; TCF, trillion cubic feet; TCM, trillion cubic meters

Table 4 Undiscovered technically recoverable resources (TRR) of some major shale oil plays

\begin{tabular}{|c|c|c|c|c|c|c|}
\hline \multirow[t]{2}{*}{ Location } & \multirow[t]{2}{*}{ Shale play } & \multicolumn{2}{|l|}{ Oil } & \multicolumn{2}{|l|}{ NGL } & \multirow[t]{2}{*}{ Source } \\
\hline & & MMBO & MMTO & MMBO & MMTO & \\
\hline Midland Basin (Permian Basin Province) & Wolfcamp & 19,948 & 2733 & 1596 & 219 & Gaswirth (2017) \\
\hline U.S. Gulf Coast Region & Eagle Ford & 853 & 117 & 2043 & 280 & Dubiel et al. (2012) \\
\hline Williston & Bakken and Three Forks & 7375 & 1010 & 527 & 72 & Gaswirth et al. (2013) \\
\hline
\end{tabular}

MMBO, million barrels of oil; MMTO, million tons of oil; NGL, natural gas liquid

\section{(5) Controls on hydrocarbon enrichment}

Hydrocarbon enrichment in the SPS primarily depends on source rock qualities, reservoir sweet spots, and sealing conditions. Moreover, hydrocarbons can even be quite abundant at low structural positions, differing from most conventional accumulations.

\section{a. Hydrocarbon-generating condition}

The hydrocarbon-generating condition is a primary factor affecting hydrocarbon enrichment. Studies indicate that there is a positive correlation between shale gas content and organic matter abundance. The higher the TOC values, the higher the shale gas content (Ross and Bustin 2009; Jarvie 2011; Guo 2013). Furthermore, source rocks should be thick enough so that the hydrocarbons generated cannot be readily expelled. In general, the greater the thickness of source rocks, the more difficult it is for the hydrocarbons to be expelled from the innermost of the source rocks, and the more hydrocarbons are retained in them. Analyses of high-yield regions of marine shale gas in North America show that those shales share some crucial attributes, including TOC $>1 \%, R_{\mathrm{o}}>1.4 \%$, and shale thicknesses generally $>30 \mathrm{~m}$ (Jarvie 2012). Otherwise, there would be insufficient shale gas accumulation and enrichment in the source rocks, given that their thermal maturities are not high enough nor their thicknesses great enough. For instance, the gas produced from the Barnett Shale is revealed to have been generated within the condensate-wet gas window $\left(1.3-2.0 \% \quad R_{\mathrm{o}}\right)$ and probably derived from both kerogen cracking and secondary cracking of previously generated non-migrated hydrocarbons (Rodriguez and Philp 2010). As another example, the Chang-7 shale source rocks of the Triassic Yanchang Formation in the Ordos Basin are dominated by type I and II kerogen and their $R_{\mathrm{o}}$ is $0.7 \%-1.2 \%$ (i.e., mainly in the "oil generation window"); hence, the generated hydrocarbons are oil-dominated, and the gas content is extremely limited (Zhao et al. 2016b).

In addition to the requirement for sufficient amounts of hydrocarbon generation, hydrocarbon expulsion efficiencies of shales are another key factor affecting shale hydrocarbon richness. The lower the hydrocarbon expulsion efficiency or the greater the amount of hydrocarbons retained in source rocks, the larger would be the quantity of hydrocarbons accumulating in the shales. According to studies by Pepper (1992) and Jarvie et al. (2007), the hydrocarbon expulsion efficiency of the Barnett Shale is approximately $60 \%$. Thus, we can infer that large-scale continuous shale gas accumulation will be possible in shales if the amount of retained hydrocarbon is approximately $40 \%$ or more of the total hydrocarbon generated. 


\section{b. Reservoir heterogeneity and sweet spots}

Source rocks as a reservoir, such as shales and coals, are not only usually poor in quality but may be also more heterogeneous relative to many other reservoirs, particularly those of conventional accumulations. The heterogeneity of a source-rock reservoir, however, is generally a propitious factor for the occurrence of abundant hydrocarbon accumulations because sweet spots can only be developed in reservoirs with certain heterogeneity. Otherwise, hydrocarbon enrichment might be unlikely if the source-rock reservoirs are highly uniform in terms of their properties. It is the reservoir heterogeneity and development of sweet spots that control the specific locations of hydrocarbon enrichment. The sweet spots in source rocks can be classified into two types: structural and non-structural. The former is represented by anticlinal sweet spots, while the latter includes geochemical sweet spots (favorable regions for TOC, $R_{\mathrm{o}}$, thickness, etc.) and petrophysical (porosity and permeability) sweet spots. Accordingly, continuous accumulations can be divided into two types, namely structural sweet-spot accumulations and nonstructural sweet-spot accumulations. In general, structural sweet-spot accumulations are characterized by higher resource abundance and producibility and relatively smaller areas of oil/gas distribution than non-structural sweetspot accumulations. For example, the Fuling Field in the Sichuan Basin seems to be a structural sweet-spot type of shale gas accumulation (Zhao et al. 2016a).

It is noteworthy that good-quality reservoirs are not always an advantageous condition for the formation of continuous hydrocarbon accumulations. That is because the accumulations would probably be of conventional nature, or oil/gas would likely escape from source rocks if the source-rock reservoirs were permeable enough to attain the quality level of conventional reservoirs. Although it is widely believed that the minimum permeability of commercial shale gas reservoirs exceeds 100 nd and shales with a permeability $>500$ nd are optimal (Zagorski et al. 2012), shale porosities of high-yield marine gas shales in North America are $<15 \%$, mainly in the range of $4 \%-7 \%$, and the permeabilities are $<1000$ nd (Jarvie 2012).

The brittleness is also a pivotal factor affecting shale oil and gas production. It has been demonstrated that producible shale ought to contain sufficient brittle minerals (e.g., quartz, feldspar, and carbonates) and their clay mineral contents should not be too high (Bowker 2007; Jarvie 2012). Furthermore, relatively high contents of brittle minerals and low contents of clay minerals not only can make shale fracturing easier, but also enable them to have higher porosity and permeability and thus be more favorable for shale oil/gas enrichment and production. Statistics and analyses have shown that most productive marine gas shales in North America are quartz rich, carbonate rich, or dominated by a combination of multiple brittle minerals, while the content of clay is subordinate (Jarvie 2012; Wilson et al. 2016; Chalmers et al. 2012). Bowker (2007) claimed that the clay mineral content of the Barnett Shale is usually less than $50 \%$. Rezaee and Rothwell (2015) noted that low clay content $(<50 \%) /$ high brittle mineral content $(>40 \%)$ is one of the key geological characteristics of a successful shale gas play. In reality, some statistics (e.g., Jarvie 2012; Wilson et al. 2016) have shown that clay mineral contents of the most successfully exploited shales in North America are less than $45 \%$.

Apart from the relative proportion of clay versus nonclay minerals, the provenance and origins of the components in shales are also critical in determining the richness and production of shale oil and gas. The components of most shales can be categorized as those of terrigenous (detrital) and autochthonous (including diagenetic) in terms of their provenance and can also be categorized as biogenic components and abiogenic components. As one of the most significant brittle minerals, quartz in shales includes biogenic, diagenetic, and detrital types. It has been suggested that the abundant presence of biogenic silica has the potential to increase rock brittleness and "fracability" (Passey et al. 2010; Slatt 2011). The primary sources of biogenic silica are diatoms, radiolaria, and sponge spicules (Katz and Everett 2016). In fact, the presence of abundant biogenic and diagenetic quartz is a crucial factor leading to the success of many marine shales in North America. By contrast, the impact of abiogenic quartz on the enrichment and production of shale oil and gas is more complicated because of the complexity of its origins, which includes detrital quartz and authigenic quartz. For most commercial marine shales, authigenic and biogenic quartz is dominant over terrigenous abiogenic quartz, while terrigenous abiogenic quartz is commonly more abundant in shales deposited in continental environments (including lacustrine, paludal and fluvial facies), in which lacustrine and paludal shales are assumed to be two most potential types of shale plays as revealed by the exploration in the Ordos Basin (Zou et al. 2017), the Bohai Bay Basin (Sun 2017; Zhao et al. 2018), and the Songliao Basin (Zhang et al. 2016) of China. For this reason, higher contents of quartz are not always conducive to hydrocarbon enrichment and production from continental shales, nor are lower contents of clay minerals. Studies of the Triassic Chang-7 lacustrine shale in the Ordos Basin indicated that the TOC content is negatively correlated with the quartz content, but positively correlated with the clay mineral content (Er et al. 2013; Zhao et al. 2016b). Because clay minerals are usually one of the major components of shale, an unduly high content of terrigenous detrital quartz or an overly low content of clay minerals is associated with a decrease in organic 
matter content in shale, which is a disadvantage to the generation of sufficient shale oil/gas, although either can increase shale brittleness, porosity, and permeability. As a result, finding an optimal balance between the contents of brittle minerals and clay and TOC in shale should be regarded as the linchpin of successful exploration and exploitation for shale oil and gas. In addition to clay content, the provenance and varieties of clay minerals appear to play an equally significant role in affecting the production of shale oil and gas. It has been suggested that the clay mineralogy of practically all of the shale reservoirs older than Upper Cretaceous is dominated by illitic clays, both in discrete form and as illite-dominated, mixed-layer, illitesmectite (I/S) (Wilson et al. 2016).

In reality, the content of clay minerals versus non-clay minerals or brittle minerals in shale and the origins of the minerals including quartz are essentially determined by depositional settings and diagenesis. It has been revealed that marine-deposited shales tend to have lower clay content and higher content of brittle minerals such as quartz, feldspar, and carbonates (Ju et al. 2014; Wilson et al. 2016), and most productive shales are siliceous, calcareous or dolomitic mudstones, or mudstones where one or a few key brittle minerals and non-swelling clay are both abundant. Moreover, the distribution of mineral components and reservoir properties in marine shales are more stable than their continental counterparts. In spite of this, the development of shale plays has revealed strong heterogeneities in marine shales (Bustin and Bustin 2012). By contrast, continental shales including lacustrine shales tend to be higher in clay content, more ductile and less responsive to hydraulic stimulation (De Silva et al. 2015), and their heterogeneities are commonly stronger. Their mineralogical composition appears to be more diverse, and the reservoir properties are presumed to be more variable. Such a more diverse nature of continental shales, particularly lacustrine shales, makes many of them probably less exploitable, while some others might have significant potential for shale oil and gas enrichment and production. For instance, the average clay mineral contents of both the Triassic Chang-7 lacustrine organic-rich shales and Upper Paleozoic paludal organic-rich mudstones (carbonaceous shales) in the Ordos Basin are commonly higher than $45 \%$, while the brittle mineral contents are relatively low (Zhao et al. 2016b; Jiang et al. 2016). The lacustrine-deposited Cretaceous Qingshankou Formation shales in the Songliao Basin may also be clay rich, with an average content of clay minerals of $55.1 \%$ at well ZK-01 (Liu et al. 2017). Nonetheless, the lacustrine shales of the upper Es$s_{4}$ and lower $\mathrm{Es}_{3}$ of the Eocene Shahejie Formation in the Dongying Depression, Bohai Bay Basin, are carbonate rich and clay poor, with an average content of authigenic carbonate of $37 \%$, clay $25 \%$, quartz $29 \%$, and feldspar $5 \%$ ( $\mathrm{Li}$
2013), which is probably one of the crucial factors accountable to the breakthrough of oil production in this shale play. According to Sun (2017), 37 wells, as of 2016, have produced shale oil at commercial rates from the Es 4 and $\mathrm{Es}_{3}$ shale of the Shahejie Formation in the Jiyang Depression, the Bohai Bay Basin.

Consequently, petroleum exploration and development of continental shales might face greater challenges compared to those of marine shales. Despite this, because some lacustrine shales are similar to producible marine shales in that non-clay minerals are preponderant and mainly authigenic, opportunities still exist for substantial discoveries of hydrocarbon accumulations in continental shales.

\section{c. Top and bottom sealing conditions}

Favorable top and bottom sealing conditions are also critical for the enrichment of continuous hydrocarbon accumulation. As far as the accumulations of shale oil/gas or CBM are concerned, the premise of their enrichment is that the hydrocarbons generated in organic-rich shales or coals were not completely expelled. The less hydrocarbons that are expelled, the more hydrocarbons are retained in the source rocks, and the more abundant the accumulated shale oil/gas and CBM. The quantity of hydrocarbons trapped within source rocks is not simply affected by the quality of source rocks per se, but also by the sealing conditions or the conditions of hydrocarbon expulsion. The conditions of sealing and expulsion of source rocks depend on the following three major factors. The first is the thickness of source rocks; the greater the thickness, the more difficult it is for the hydrocarbon to be expelled and the more hydrocarbons that are retained. The second is the top and bottom sealing conditions, as more hydrocarbons would be held in source rocks with effective top and bottom seals. The third is the intensity of tectonic activities, as strong tectonic activities can lead to the development of more fractures, and thus conditions would become more favorable for hydrocarbon expulsion from source rocks and less favorable for hydrocarbon accumulation within them. As a consequence, source rocks with sufficiently great thickness and good quality, and propitious top and bottom sealing conditions, but moderately developed fractures, are advantageous for shale oil/gas and CBM enrichment. The major gas-rich shales in North America are exactly those possessing good to excellent top and bottom sealing conditions. For instance, the Barnett Shale in the Fort Worth Basin and the Devonian-Carboniferous New Albany Shale in the Illinois Basin have tight limestones acting as both top and bottom seals; for the Devonian Marcellus Shale in the Appalachia Basin and the Devonian Antrim Shale in the Michigan Basin, the top seals are shales, while the bottom seals are limestones; the top seal of the Devonian Woodford Shale in the Acoma Basin is comprised of limestones, 
while the bottom seal consists of sandstones/limestones; the Upper Jurassic Haynesville Shale in the East TexasNorth Louisiana Basin is overlain by sandstones and underlain by limestones, whereas the Carboniferous Fayetteville Shale in the Acoma Basin is overlain by a limestone interval and underlain by a sandstone formation (Ground Water Protection Council 2009).

Similarly, the Fuling Shale Gas Field in the Sichuan Basin also has excellent top and bottom sealing conditions, which play a crucial role in the shale gas enrichment and preservation (Zhao et al. 2016a). The top seal of this Silurian Longmaxi Formation Shale Gas Field is a thick mudstone sequence with lower organic matter abundance and low porosity and permeability, while the bottom seal is the widely distributed tight limestones of the Ordovician Jiancaogou Formation $\left(\mathrm{O}_{3} \mathrm{j}\right)$, which is $45-50 \mathrm{~m}$ in thickness and has a porosity of $0.61 \%-1.66 \%$ (averaging $1.01 \%$ ) and a permeability of $0.0058-0.1092 \mathrm{md}$ (averaging 0.0201 md) in well DS1 (Guo 2013). In spite of this, diffusion of natural gas in the Fuling Shale Gas Field might be noticeable. According to Dai et al. (2016, 2017), shale gas from this field displays a complete carbon and hydrogen isotopic reversal (i.e., $\delta^{13} \mathrm{C}_{1}>\delta^{13} \mathrm{C}_{2}>\delta^{13} \mathrm{C}_{3} ; \delta^{2} \mathrm{H}_{1}>\delta^{2-}$ $\mathrm{H}_{2}>\delta^{2} \mathrm{H}_{3}$, which they interpreted as the result of secondary alteration like, among others, oil or gas cracking and diffusion at high temperatures.

Likewise, good sealing is also significant for CBM enrichment (Song et al. 2015).

\subsection{Tight petroleum system (TPS)}

In this article, tight oil and gas accumulation refers to that occurring in low-permeability reservoirs that are not source rocks or shale, which primarily includes petroleum accumulations in tight sandstone and tight carbonate reservoirs. Accordingly, such reservoirs are known as tight reservoirs. Two models were proposed to interpret hydrocarbon accumulations in such tight reservoirs as tight sandstones, which are: (1) the deep-basin or basin-centered gas model, also known as the continuous accumulation model; and (2) the conventional trap-controlled accumulation model. Recently, Zhao et al. (2012a, 2013, 2016a) proposed a new model termed quasi-continuous accumulation and demonstrated that tight oil and gas are dominated by quasi-continuous accumulation, while discontinuous (conventional trap-controlled) accumulations are of subordinate importance. Zhao et al. (2016a) also argued that the so-called continuous (basin-centered) accumulations actually do not exist in non-source-rock tight reservoirs such as tight sandstones. Hence, two types of hydrocarbon accumulations can be caused in tight petroleum systems, namely the quasi-continuous accumulation and discontinuous accumulation.

\subsubsection{Quasi-continuous tight accumulations (QTA)}

The quasi-continuous hydrocarbon accumulation is defined as an accumulation consisting of a group of petroleum reservoirs that are adjacent and closely related with no distinct boundaries. They are common in tight reservoirs, especially tight sandstones. Examples of such accumulations include the Upper Paleozoic tight sandstone gas accumulations and the Triassic Yanchang Formation tight sandstone oil accumulations in the Ordos Basin, the Triassic Xujiahe Formation tight sandstone gas accumulations in the central Sichuan Basin, the Cretaceous Fuyu and Gaotaizi tight sandstone oil accumulations in the Songliao Basin, some tight Ordovician carbonate oil and gas accumulations in the Tarim Basin, and many tight sandstone oil/gas accumulations in North American basins. The main characteristics of quasi-continuous accumulations are elaborated below.

\section{(1) Reservoirs}

Quasi-continuous accumulations dominantly occur in tight reservoirs with permeabilities of approximately $<1$ md. It should be noted that the upper and lower porosity and permeability limits of tight reservoirs are not uniform, but are dependent on the specific geologic circumstances of petroleum accumulations, and hence vary in different basins or regions. For example, Cao et al. (2013b) have demonstrated that the upper and lower limits of the reservoir properties for the Upper Paleozoic tight gas accumulations even differ among various pay zones in the eastern Ordos Basin.

Moreover, reservoirs of quasi-continuous accumulations commonly become tight prior to hydrocarbon charging. In the Ordos Basin, for instance, the Upper Paleozoic sandstones were charged mostly in the Early Cretaceous when the sandstones had already become tight (Zhao et al. 2005; $\mathrm{Fu}$ et al. 2008). Tight sandstone reservoirs in the Triassic Xujiahe Formation of the central Sichuan Basin and the Middle Jurassic Shaximiao Formation of the western Sichuan Basin, where quasi-continuous accumulations are widely distributed, also became tight mostly prior to hydrocarbon charging (Zhu et al. 2008; Lü et al. 2015). According to Zhu et al. (2008), during the formation of Triassic Xujiahe tight sandstone reservoirs in central and western Sichuan Basin, mechanical compaction contributed most to porosity reduction, while quartz overgrowths of stages II and III were another significant contributor. The evolution of the reservoirs into the tight state primarily occurred in stage A of the mid-diagenesis phase (roughly equivalent to the burial depth of 2000-3500 $\mathrm{m}$, and the $R_{\mathrm{O}}$ was approximately $0.5 \%-1.3 \%$ ) or even earlier, while the organic matter became mature during the stage II quartz overgrowths. However, the content of 
hydrocarbon gas is significantly higher in fluid inclusions of the stage III quartz overgrowths than that of stage II, indicating that large quantities of natural gas were trapped during the stage III quartz overgrowths. In other words, the major gas-charging event occurred after the Xujiahe sandstones became tight. Similarly, the Yinan 2 Jurassic gas reservoir in the Tarim Kuqa Foreland Basin was also shown to have become tight prior to hydrocarbon charging. The tight reservoirs (porosity $<12 \%$ ) were formed in the Neogene Kangcun Period (12-8 Ma), and natural gas was charged during 5-0 Ma (Li et al. 2013b).

Because the reservoirs of quasi-continuous accumulations have mostly become tight prior to hydrocarbon charging, they do not simply play a critical role in selfsealing so as to avoid substantial escaping of the charged hydrocarbons, but also make long-distance migration of the oil and gas impossible. Since pore throats of tight reservoirs are extremely fine, and their capillary resistance and reservoir heterogeneity are strong, it is unlikely for the charged hydrocarbons to concentrate over a restricted area and form a conventional accumulation. Meanwhile, a continuous accumulation or basin-centered gas accumulation typically characterized by gas-water inversion also can hardly occur in such a highly heterogeneous reservoir. On the other hand, it is more likely for quasi-continuous accumulations to occur in such reservoirs over large areas. Otherwise, if the reservoir had been charged prior to the major period of porosity loss, then long-distance migration would have taken place due to good reservoir qualities. Under such circumstances, hydrocarbons would tend to migrate toward and accumulate at high structural positions to form conventional hydrocarbon accumulations. After the accumulation, the original oil and gas accumulations might still remain around the paleo-high positions, even if the reservoirs become tight afterward and the previously formed conventional accumulations might be modified to some extent. Hence, in reservoirs becoming tight after hydrocarbon charging, a quasi-continuous accumulation extending from a basin center to the flanks and uncontrolled by structure highs would be implausible unless the supply of hydrocarbons were extremely plentiful.

\section{(2) Oil/gas and water distribution}

Similar to continuous accumulations, quasi-continuous accumulations are also characterized by extensive distribution and large volumes of reserves. Their distribution generally ranges from hundreds to thousands of square kilometers, with some even reaching tens of thousands of square kilometers. For example, the geologic reserves of natural gas in the Sulige Field of the Ordos Basin are as much as $3.9 \times 10^{12} \mathrm{~m}^{3}$ as of the end of 2013, and the gasbearing area is $>60,000 \mathrm{~km}^{2}$ (Zou et al. 2015). With respect to gas accumulations in the Triassic Xujiahe
Formation tight sandstones of the central Sichuan Basin, the Anyue, Hechuan, and Guang' an fields are estimated to have gas-bearing areas of $749 \mathrm{~km}^{2}, 1058 \mathrm{~km}^{2}$, and $579 \mathrm{~km}^{2}$, and geologic reserves of $2082 \times 10^{8} \mathrm{~m}^{3}$, $2299 \times 10^{8} \mathrm{~m}^{3}$, and $1356 \times 10^{8} \mathrm{~m}^{3}$, respectively (Wei et al. 2013; Li et al. 2013a). The areal distribution of the Cretaceous Fuyang tight oil accumulations in the Songliao Basin is up to $11,000 \mathrm{~km}^{2}$, while that of the Gaotaizi tight oil accumulations is at least $2000 \mathrm{~km}^{2}$.

Unlike continuous accumulations, a quasi-continuous accumulation consists of multiple small- to medium-sized reservoirs adjacent to each other, and the distribution of petroleum reservoirs appears to be "continuous" on the plane view, but discontinuous on the profile view (Fig. 4). On the plane view, the stacking of multiple intervals of oil/gas reservoirs makes the accumulation appear to be "continuous," while the distribution of the oil/gas reservoirs is laterally discontinuous on a profile view due to the discontinuity of the reservoirs. That is why such a group of reservoirs is referred to as a quasi-continuous accumulation. As a result, no real dry holes are usually present in such a petroleum accumulation, but dry beds are possible.

Moreover, edge water or bottom water is absent or only partially present, which is also a significant attribute of quasi-continuous accumulations. For example, giant tight Upper Paleozoic gas fields, such as the Sulige and Shenmu, and nearly all the large tight oil accumulations in the Chang 6, 7, and 8 pay zones of the Triassic Yanchang Formation in the Ordos Basin, are typical quasi-continuous accumulations with no edge water or bottom water, or with edge water limited to only the lower southwest structural positions of the Yulin and Zizhou tight gas fields (Zhao et al. 2013). In addition, incomplete edge/bottom water can also be found in some giant Triassic Xujiahe Formation tight gas fields such as the Guang'an and Hechuan fields in the central Sichuan Basin (Bian et al. 2012). This is in contrast with conventional oil and gas accumulations, which have clear boundaries because of the presence of complete edge/bottom water. There are two possible reasons for the lacking or the incompleteness of edge/bottom water in quasi-continuous accumulations. First, the reservoirs had already become tight before the charging of hydrocarbons, leading to possibly negligible free water left in the reservoirs when the accumulation occurred. Second, such a type of accumulation usually occurs in relatively gentle structural settings, such as gentle sags and slopes, so that the differentiation of oil/gas and water is poor, leading to the complex distribution of oil/gas and water in the tight reservoirs. However, if the structural relief is big enough, some degree of oil/gas-water differentiation and resulting edge/bottom water will be possible. The occurrence of partial edge water in the Yulin, Zizhou, Guang'an, and 


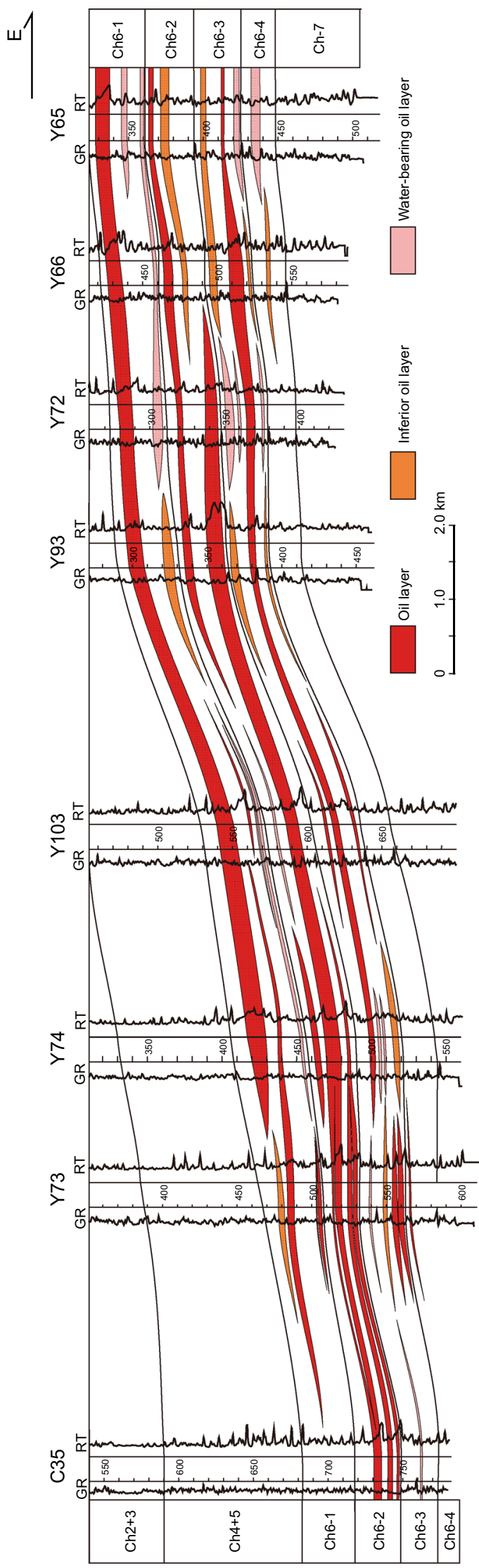

4 Fig. 4 Cross section of a quasi-continuous oil accumulation in the Chang- 6 tight sandstones of the Triassic Yanchang Formation in the Ordos Basin, showing quasi-continuous distribution of oil-bearing beds and absence of bottom water and edge water. The Chang- 6 reservoirs are predominated by tight sandstones in the Ordos Basin

Hechuan gas fields might be related to structural differentiation.

It is noteworthy that the phenomenon of water occurring at high structural positions with oil/gas located in downward positions in a reservoir interval was frequently considered to be an oil/gas-water inversion, and widely believed to be a key signature of basin-centered or deepbasin oil/gas accumulations as defined by Masters (1979, 1984) and Law (2002). Nevertheless, with the expansion of exploration and development and the increase of drilling intensity, it has been confirmed that what was once thought to be the phenomenon of regional oil/gaswater inversions is virtually just an illusion such that the basin-centered gas hypothesis was even regarded as a "chimera" by Fassett and Boyce (2005). It has been ascertained that the observed downdip hydrocarbon-filled reservoirs and the juxtaposed updip water-filled reservoirs in the same interval do not make up of a continuity of reservoirs, but are separated from each other. In other words, they are mutually independent and constitute separate traps. Consequently, it is believed that the so-called oil/gas-water inversions are invalid and could not be viewed as an indicator of the basin-centered accumulation model. In reality, such a phenomenon is frequently observed in the formation and distribution of conventional oil and gas accumulations and is caused by the inadequate supply of hydrocarbons. Indeed, no genuine regional oil/gas-water inversion in a continuous reservoir has been confirmed. In actuality, even if a regional oil/gas-water inversion could have been caused in geologic history, it would be hard for it to be preserved, because the presence of a regional oil/gas-water inversion is a hydraulic imbalance. The eventual result of its evolution would be the disappearance of such an imbalance and the establishment of a normal distribution of oil/gas and water (Zhao et al. 2013). Thus, it would be improbable for a regional oil/gas-water inversion to be formed and sustained over a long geological time frame. As a consequence, the traditional basin-centered gas model has been doubted and denied by an increasing number of researchers (e.g., Shanley et al. 2004; Fassett and Boyce 2005; Camp 2008; Cumella et al. 2008; McCullagh and Hart 2010; Cant 2011; Zhao et al. 2012a, 2013, 2016a).

\section{(3) Hydrocarbon charging and migration}

Unlike continuous accumulations that occur within source rocks, quasi-continuous accumulations are 
dominated in tight reservoirs that are adjacent to source rocks. They are also distinguished from conventional accumulations in terms of migration. While dominant migration pathways that enable hydrocarbons to migrate over long distances are developed and necessary for conventional accumulations, they are unnecessary for quasicontinuous accumulations. Although the charging and migration pathways for quasi-continuous accumulations can be either of a pore throat type or a fracture type, fractures must be numerous, widespread in distribution, and small in scale so that no dominant migration pathway occurs. In fact, the charging of hydrocarbons from source rocks into tight reservoirs is pervasive over large areas and the migration within tight reservoirs is in short distance. Hence, quasi-continuous accumulations are the outcome of primary migration and short-distance secondary migration. Analyses of the relationship between gas components and source rock maturity show that methane content, dryness index $\left(\mathrm{C}_{1} / \mathrm{C}_{1}-5\right), \delta^{13} \mathrm{C}_{1}$, and $\delta^{13} \mathrm{C}_{1}-\delta^{13} \mathrm{C}_{2}$ of natural gases from each Upper Paleozoic tight sandstone pay zone in the Ordos Basin have a strong positive correlation with the in situ Upper Paleozoic source rock maturities, indicating that the variation in gas composition and carbon isotopes is closely related to the thermal evolutionary degree of in situ or nearby source rocks, and there is no notable fractionation of the gas component and carbon isotopes caused by lateral migration (Zhao et al. 2014). This implies that the natural gas accumulations are the result of short-distance migration instead of long-distance or large-scale lateral migration.

With regard to the driving force of hydrocarbon migration, it has been argued that abnormally high pressures derived from hydrocarbon generation are the major contributor, while diffusion forces caused by hydrocarbon concentration gradients are also significant for gas migration. Nevertheless, buoyancy is insignificant or even negligible. Consequently, the main flow mode is presumed to be in the form of overpressure-driven flow, followed by diffusion flow caused by the difference of hydrocarbon concentrations. Both types of migration have been revealed in the Upper Paleozoic tight gas accumulations of the Ordos Basin.

\section{(4) Traps}

In contrast to continuous accumulations, quasi-continuous accumulations are controlled by some traps to a certain degree, but the traps are mainly non-anticlinal (especially stratigraphic) rather than anticlinal. Tight reservoirs are generally thin and small in terms of the scale of single reservoirs, and their rock properties vary greatly relative to conventional reservoirs. In such cases, most tight reservoirs can easily be charged sufficiently such that the hydrocarbon accumulations could surpass the boundary of an anticlinal trap, if any, because the base of anticlinal traps is open. On the other hand, stratigraphic traps are generally well developed and therefore are dominant for hydrocarbon accumulations in tight reservoirs, because tight reservoirs commonly have stronger heterogeneities and larger lateral variation of lithologies and rock properties compared to conventional reservoirs.

For tight sandstones, most quasi-continuous accumulations are formed in fluvial, lacustrine, deltaic, and marine deposits. The tight sandstones of these deposits, particularly those deposited in continental environments, commonly exhibit strong heterogeneities and poor lateral continuities and generally consist of numerous lenticular sand bodies close to each other but unequal in size. Therefore, an accumulation caused in a tight formation is usually composed of numerous lenticular oil/gas reservoirs adjacent to each other. Because each lenticular reservoir is a self-sealing body, preservation conditions for such oil/gas accumulations are generally excellent.

The strong heterogeneity of tight reservoirs determines that quasi-continuous accumulations are mainly formed in stratigraphic traps, followed by structural-stratigraphic traps governed primarily by lithological variation and secondarily by structural factors. For instance, almost all the Upper Paleozoic tight sandstone gas fields and Triassic tight sandstone oil fields in the Ordos Basin, and some Triassic Xujiahe Formation tight sandstone gas fields, such as the Anyue Field in the central Sichuan Basin, are formed in typical stratigraphic traps. Although there is an anticlinal background to the $\mathrm{Xu}-2$ gas accumulation of the Hechuan Field (Bian et al. 2012), the gas and water distribution is basically independent of the structure, as the reservoirs are sufficiently gas-charged at low structural positions below the spill-point of the anticlinal trap, while the reservoirs at the high structural positions are not always sufficiently gasfilled. In effect, the distribution of the Xu-2 pay zones in the Hechuan Field is principally controlled by the variation of reservoir lithologies and rock properties and the traps are primarily stratigraphic (Fig. 5). Nevertheless, the Guang'an Gas Field is mainly ruled by a structural-stratigraphic combination trap (Li et al. 2013a).

In addition, multiple fault traps or numerous fault blocks adjacent to each other can also lead to quasi-continuous accumulations. The Fuyang tight oil accumulation in the Songliao Basin was, for instance, once thought to be a deep-basin oil accumulation (e.g., Hou et al. 2006), but is actually a different type of quasi-continuous accumulation, similar to the Cretaceous Gaotaizi tight oil accumulation in the same basin. Both comprise numerous oil accumulations controlled by fault-block traps or fault-stratigraphic traps, and no notable edge water and bottom water have been detected. The water-bearing sandstone reservoirs at higher structural positions are actually disconnected from the 


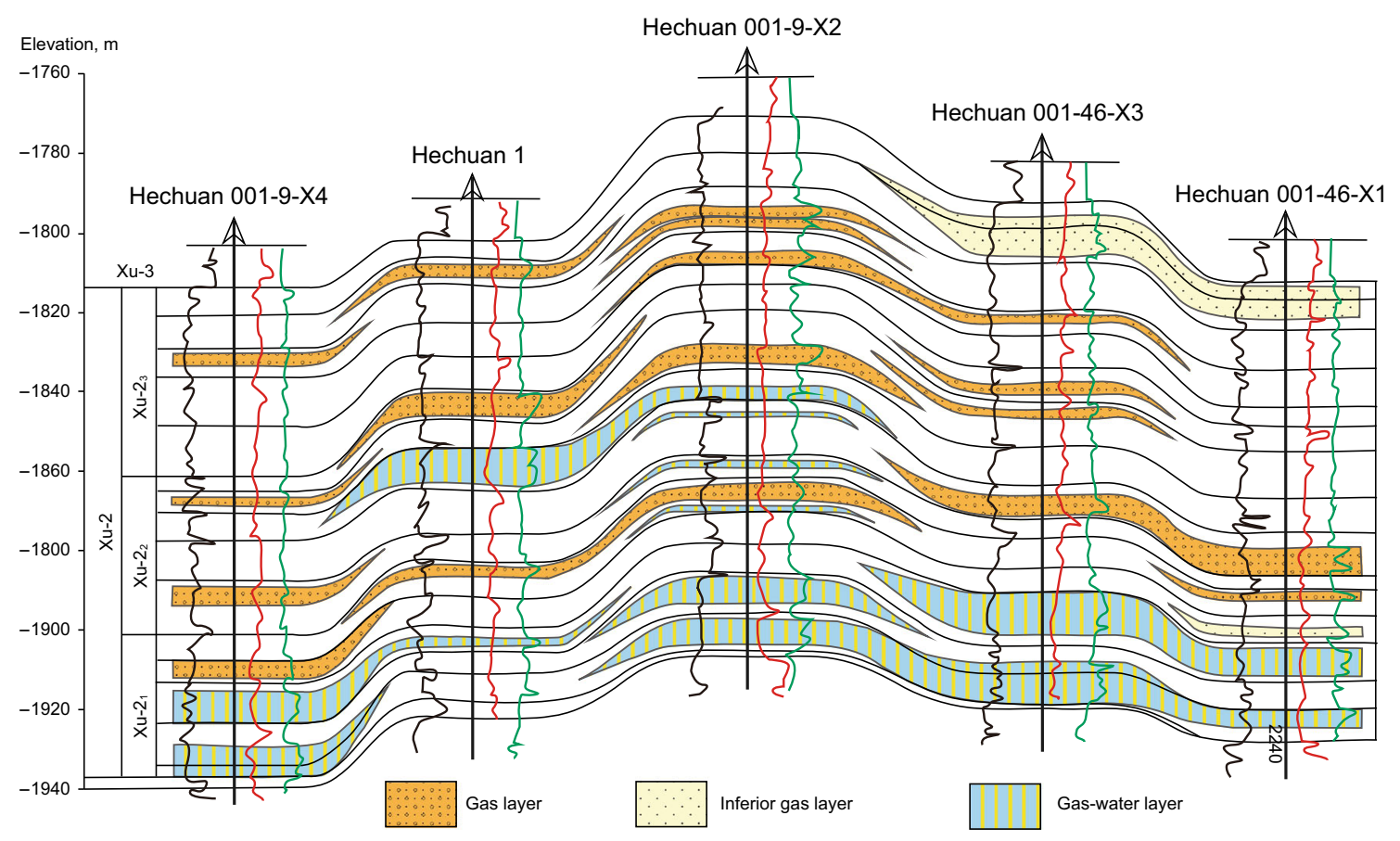

Fig. 5 Cross section of the $\mathrm{Xu}-2$ tight gas accumulation of the Triassic Xujiahe Formation in the central Sichuan Basin (Bian et al. 2012). Both the gas beds and gas-water beds are tight sandstone reservoirs and can occur at either structural low or high positions,

downdip oil-producing sandstones because the sandstone intervals are faulted into multiple segments and each of them constitutes a separate fault trap or fault-stratigraphic trap. Obviously, such oil-water distribution pattern is not a genuine oil-water inversion. Thus, it can be concluded that the Fuyang and Gaotaizi tight oil accumulations should not be attributed to deep-basin or basin-centered oil accumulation; instead, they belong to quasi-continuous accumulations comprising multiple neighboring faulted reservoirs.

\section{(5) Controls on hydrocarbon enrichment}

Investigations have revealed that quasi-continuous accumulations mainly occur in gentle depressions and slopes and that source kitchen, reservoir, seal, and migration conditions are major factors in controlling the abundance of the accumulations. The reason why quasicontinuous accumulations occur primarily in gentle depressions and slopes is that such settings favor the deposition of large areas of source rocks and tight reservoirs compared to those deposited in a steep and narrower basin, and their gentle stratigraphic framework is disadvantageous for buoyancy-driven migration that could result in local oil/gas concentrations. As a result, such structural settings are more suitable for the occurrence and enrichment of extensive quasi-continuous oil and gas accumulations. showing the distribution of gas and water is independent of structural relief. Note that the curves beside each well are GR (dark), RT (red) and porosity (green) from left to right, respectively

Among all the relevant factors, hydrocarbon-generating conditions are fundamental in affecting the enrichment of quasi-continuous accumulations. Large areal distribution of source rocks and high organic matter contents are more favorable for the occurrence of quasi-continuous accumulations. For instance, the extensive tight sandstone oil accumulations of the Triassic Chang 6,7, and 8 pay zones in the Ordos Basin are closely linked to the high-quality Chang-7 shale source rock. This source rock is widely distributed, with an effective distribution area of approximately $10 \times 10^{4} \mathrm{~km}^{2}$ and high-quality source rocks of nearly $5 \times 10^{4} \mathrm{~km}^{2}$. Its thickness generally ranges from $30-60 \mathrm{~m}$, with a maximum thickness of $130 \mathrm{~m}$. The residual organic carbon content is mainly in the range of $6 \%-22 \%$, with an average TOC of $13.75 \%$ and the highest reaching up to $30 \%-40 \%$. The $R_{\mathrm{o}}$ is $0.85 \%-1.15 \%$, while the average hydrocarbon expulsion rate can reach $72 \%$ (Zhang et al. 2006). In addition, the formation of the giant Upper Paleozoic tight sandstone gas fields including the Sulige, Yulin, Zizhou, Shenmu, and Daniudi in the Ordos Basin is also closely connected with the basin-wide distribution of Upper Paleozoic coal source rocks. This set of source rocks covers almost the whole basin and is commonly in a highly mature to over-mature stage, with the gas-generating intensity mainly in the range of $(10-40) \times 10^{8} \mathrm{~m}^{3} / \mathrm{km}^{2}$. Hence, the conditions are favorable for the formation of widespread tight gas accumulation. Exploration has shown that almost 
all regions in the Ordos Basin with gas-generating intensity greater than $10 \times 10^{8} \mathrm{~m}^{3} / \mathrm{km}^{2}$ are potential places for large tight gas accumulations (Zhao et al. 2012a; Cao et al. 2013a).

In addition to source kitchen conditions, reservoir and sealing conditions are two other essential factors. With respect to reservoirs, not only widespread distribution and certain heterogeneities are indispensable for quasi-continuous accumulations, but the development of sweet spots is also significant to hydrocarbon enrichment and production. As far as the controlling effects of sealing conditions (including top and bottom seals) are concerned, it can be observed that vertical distribution of high-quality sealing beds usually determines the uppermost intervals of the accumulations above the source rocks or lowest intervals below the source rocks. Moreover, sealing conditions are of great significance to the richness of tight oil and gas accumulations, whereby high-quality seals favor the enrichment of oil/gas in tight reservoirs.

It should be noted that although hydrocarbon enrichment is favored by better conditions of source rocks, reservoirs, seals, and other necessary elements, it is virtually impossible for all these factors to concurrently achieve their respective best conditions. In nature, the sufficient development of any one of the above factors is commonly at the expense of other conditions. For instance, assuming that the condition of hydrocarbon generation in a given region is adequately developed (i.e., the thickness of source rocks and the abundance of organic matter attain their maximum), the reservoir condition therein is commonly less developed. In contrast, if the reservoir quality is excellent (large reservoir thickness and excellent rock properties), then the hydrocarbon-generating and sealing conditions may be relatively inferior. As a result, the most favorable conditions for the enrichment of tight oil/gas exist where an optimal association of source, reservoir, sealing, and all other necessary conditions is realized. This ought to be a universal rule for various oil and gas enrichment.

\subsubsection{Discontinuous tight accumulations (DTA)}

Discontinuous tight accumulations (DTA) are remarkably different from quasi-continuous accumulations, but similar to conventional accumulations in many aspects. For instance, both are discontinuous and confined by conventional traps (see the following part regarding CPS for details). The following is a discussion of the main characteristics of the DTA.

\section{(1) Traps}

Different from the QTA, which is mainly controlled by non-anticlinal traps, the DTA is strictly governed by various conventional traps, especially structural traps. In fact, most DTAs have been found to occur in anticlinal traps, followed by fault traps and stratigraphic-structural combination traps.

The anticlinal trap is the most common type of trap for DTAs. The Dina 2 and Dabei Gas Fields in the Kuqa foreland region of the Tarim Basin, and the Zhongba, Pingluoba, and Bajiaochang Gas Fields in the foreland region of the western Sichuan Basin are typical examples. In the Dabei Gas Field (Fig. 6), natural gas is confined in an anticlinal or a faulted anticlinal trap. This field's major pay zone of the Lower Cretaceous Bashijiqike Formation $\left(\mathrm{K}_{1} b s\right)$ is a tight sandstone gas-producing reservoir, with porosities ranging from $5.7 \%$ to $7.9 \%$ (averaging $7.0 \%$ ) and permeabilities in the range of 0.06-0.29 md (averaging $0.12 \mathrm{md}$ ) ( $\mathrm{Li}$ et al. 2013a). The proven reserves of natural gas are as much as $1093 \times 10^{8} \mathrm{~m}^{3}$. As another example, the Dina 2 Gas Field is also a typical anticlinal trap, with a gas-bearing area of $125 \mathrm{~km}^{2}$, and proven reserves of $1752 \times 10^{8} \mathrm{~m}^{3}$. The porosity of its Paleogene reservoirs ranges from $7.5 \%$ to $10.6 \%$, with an average of $9.5 \%$, and the permeability ranges between 0.20 and $1.41 \mathrm{md}$, with an average of $1.08 \mathrm{md}$ (Wei et al. 2013).

Fault traps are a subordinate type of trap in terms of their importance to DTAs. The Jonah Gas Field in the Greater Green River Basin of the Rocky Mountains is likely a typical example. As a field of fault traps, the Jonah was once considered to be a basin-centered gas accumulation, but Hanson et al. (2004) and Shanley et al. (2004) showed its trap type is structural. In fact, it is a tight sandstone field ruled by fault traps, with an area of only $91 \mathrm{~km}^{2}$ and reservoirs of compartmentalized fluvial sand bodies in the Upper Cretaceous Lance Formation (Camp 2008). The field is bounded by two nearly vertical shear faults on the south and west sides, forming a wedge block that rises toward the southwestern corner, with the fault displacement being usually less than $60 \mathrm{~m}$. It has been argued that gas production rate at the high structural position is better than that at the low structural position (Hanson et al. 2004), indicating that gas production is affected to some extent by the structure.

Stratigraphic-anticlinal combination traps can also be discerned in some discontinuous tight oil and gas accumulations. This type of accumulation is mainly controlled by structural features and secondarily by lithology. For instance, the Lower Jurassic Badaowan gas accumulation in the Baka Gas Field of the Tuha Basin occurs in a long, narrow E-W-trending nose-shaped structure plunging eastward. The reservoir is a braided river delta deposit, and the major sand bodies were deposited in the braided distributary channels of a delta plain and a delta front. The reservoir porosity ranges between $2 \%$ and $7 \%$, with an average of $4.4 \%$, while the air permeability is less than 0.2 md, with samples $<0.05$ md accounting for at least $50 \%$ of 


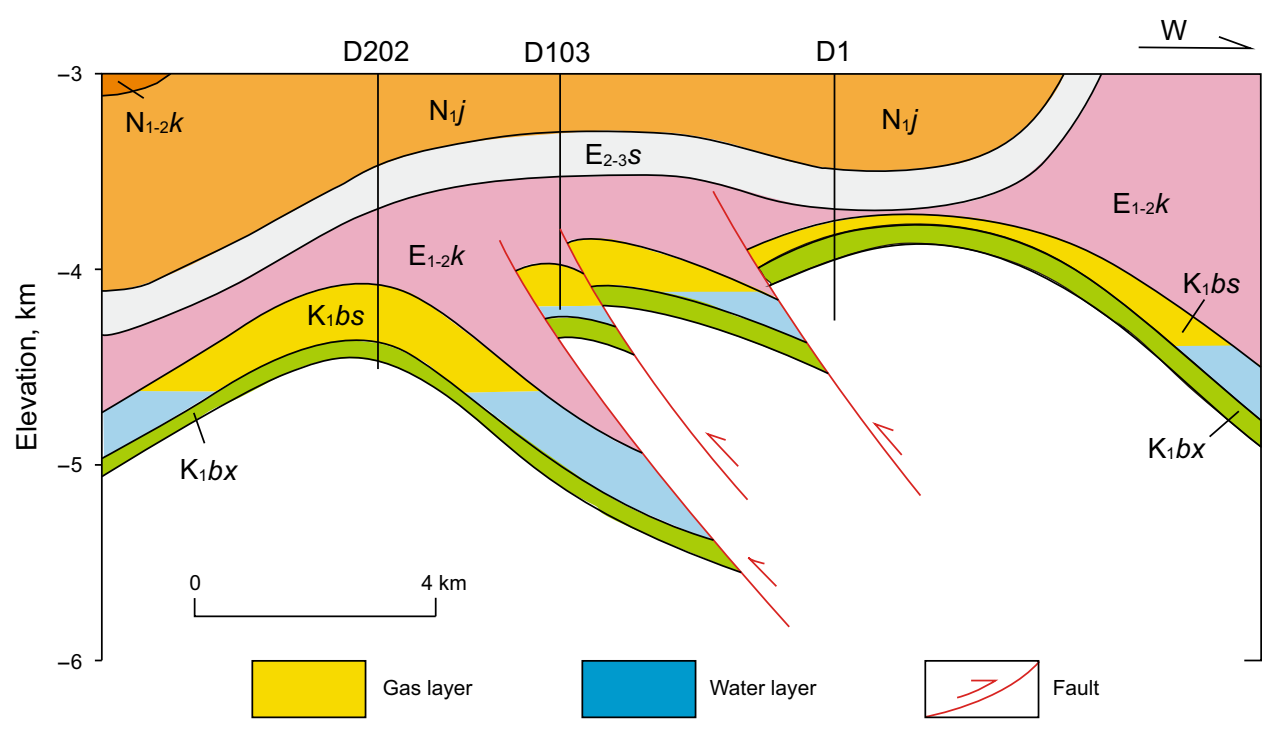

Fig. 6 Cross section of the Dabei Gas Field in the Kuqa Foreland Depression of the Tarim Basin (Dai et al. 2012), showing the presence of edge water. The gas-producing $\mathrm{K}_{1} b s$ is dominated by tight sandstones. $\mathrm{N}_{1-2} k$-Miocene-Pliocene Kangcun Formation; $\mathrm{N}_{1} j-$

the total samples. According to the analysis of the test and production data, nearly all gas-producing wells are located at higher positions of the faulted anticline, while low-yield wells are distributed at both the higher positions and the eastern and western flanks, but dry wells are mainly observed at the southern and northern flanks of lower structural positions (Wang et al. 2014).

\section{(2) Edge water and bottom water}

This type of oil/gas accumulation may or may not contain edge water and bottom water. Accordingly, the DTAs can be divided into typical DTAs (with edge water or bottom water) and atypical DTAs (without edge water and bottom water) (Zhao et al. 2013).

The typical DTA is identical to conventional oil/gas accumulations in that both have complete edge water or bottom water. For instance, notable edge water has been indicated in the Dabei Gas Field (Fig. 6). Another example is the Dina 2 Gas Field, where bottom water was reported (Li et al. 2013b).

The atypical DTA is an accumulation with neither edge water nor bottom water. The Lower Jurassic Badaowan Formation gas accumulation in the Baka Gas Field of the Tuha Basin might belong to this type (Wang et al. 2014).

\section{(3) Reservoirs}

One of the significant differences between DTAs and conventional accumulations is the quality of reservoirs.
Miocene Jidike Formation; $\mathrm{E}_{2-3} \mathrm{~s}$-Eocene-Oligocene Suweiyi Formation; $\mathrm{E}_{1-2} k$-Paleocene-Eocene Kumugeliemu Formation; $\mathrm{K}_{1} b s-$ Lower Cretaceous Bashijiqike Formation; $\mathrm{K}_{1} b x$ - Lower Cretaceous Baxigai Formation

The former has a tight reservoir, while the latter has a good-quality or conventional reservoir. The tight properties of the reservoirs are the only common features of DTAs and QTAs. However, the major difference is that the QTA reservoirs generally have porosity reduced prior to hydrocarbon charging, whereas the DTA reservoirs could have become tight either predating or postdating hydrocarbon charging event. Accordingly, DTAs can be divided into the following two categories:

\section{a. Primary DTA}

The reservoirs of this type have their porosity reduced mainly prior to hydrocarbon charging. Yang and Pang (2012) argued that the $\mathrm{Xu}-2$ and $\mathrm{Xu}-4$ reservoirs of the Upper Triassic Xujiahe Formation in the western Sichuan Depression had become tight primarily during the MiddleLate Jurassic (with a porosity of $12 \%$ ), while the major oil/gas-charging process occurred at two stages: (1) EarlyLate Jurassic oil charging, slightly earlier than the reservoir becoming tight; and (2) Late Jurassic to Late Cretaceous gas charging. Considering that natural gas in this region is dominantly generated from coals of the Triassic Xujiahe Formation, and only a very small quantity of oil was generated from such source rocks (Yang and Pang 2012), we believe that gas charging in this region took place primarily after the reservoir had become tight. A study by Luo et al. (2012) on the diagenetic history of the $\mathrm{Xu}-2$ reservoirs in the Dayi region of the western Sichuan 
Depression has obtained similar results. In this region, the porosity reduction of $\mathrm{Xu}-2$ reservoir occurred during the Middle-Late Jurassic, with a final porosity of approximately $7 \%-8 \%$, while the timing of oil generation and emplacement predated that period, and extensive gas generation and expulsion occurred after the tight transformation of the reservoir.

Another example is the Lower Jurassic Badaowan gas accumulation in the Baka Gas Field of the Tuha Basin. In this region, the gas generation and expulsion of the Lower Jurassic coal-bearing source rocks occurred during the Himalayan Stage, while the reservoir achieved tightness in the Late Jurassic when the porosity was reduced to less than $10 \%$ (Wang et al. 2014).

\section{b. Secondary DTA}

The reservoirs of this type are charged prior to their porosity loss. Because the reservoir had not been transformed into a tight state during the period of hydrocarbon charging, buoyancy is commonly the principal driving force for hydrocarbon migration. Oil/gas would migrate toward and accumulate at structural highs, forming structural or structural-stratigraphic accumulations with either edge water or bottom water. After accumulation, the formerly formed oil/gas accumulations with edge water or bottom water would be left nearby where they occurred as long as the structural deformation is not too strong, although the reservoir becomes tight due to diagenesis and the original accumulation might be altered to some extent because of structural changes.

An example is the Dina 2 Gas Field, where the gas charging of the Paleogene gas reservoir was initiated at roughly $5 \mathrm{Ma}$, and the sandstone reservoir had not evolved into tight state until the Xiyu Period (2-0 Ma) (Li et al. 2013b). Therefore, this gas accumulation is a secondary DTA. Hanson et al. (2004) argued that gas charging in the Lance Formation of the Jonah Field occurred before the reservoir became tight and that the accumulation is the result of vertical and lateral migration driven by buoyancy.

Another significant difference between the two types of DTAs is that the primary DTAs normally have neither edge water nor bottom water, but only incomplete edge water or bottom water, which is similar to QTAs. On the other hand, the secondary DTAs commonly have either edge water or bottom water, resembling conventional accumulations or discontinuous accumulations.

\section{(4) Hydrocarbon Distribution}

Because DTAs are controlled by various conventional traps, especially structural traps, they occur primarily in areas where folds and faults are developed, such as in foreland basins. The aforementioned Kuqa and western Sichuan Basins are typical examples. In addition, DTAs can also occur in areas where the dip angle of strata or the amplitude of anticlines, if any, is big enough.

\subsection{Conventional petroleum system (CPS)}

The CPS occurs in conventional reservoirs (air permeability generally $>1 \mathrm{md}$ ) and is characterized by discontinuous or conventional hydrocarbon accumulations. The main features of CPSs are well known, and a brief summary is provided herein for the purpose of comparison with the aforementioned types of PS.

\section{(1) Accumulation}

Conventional oil/gas accumulations can occur singly, but more often are formed in zones. Such accumulations have unambiguous boundaries and complete edge water or bottom water, and their distribution is discrete or discontinuous, which is in a remarkable contrast with the continuous and quasi-continuous accumulations. Thus, this type of accumulation is termed the discontinuous accumulation or conventional accumulation.

\section{(2) Migration}

Discontinuous (conventional) accumulations mainly occur in reservoirs that either possess good qualities or are close to a fault. As a result, migration pathways are developed so that oil and gas can readily migrate. Under such circumstances, hydrocarbons tend to migrate toward and concentrate at higher structural positions. The driving force for secondary migration is primarily buoyancy. Where overpressure is developed, it also plays a significant role as a driving force for oil/gas migration, particularly for primary migration.

\section{(3) Traps}

The occurrence of discontinuous (conventional) accumulations is strictly controlled by trapping mechanisms, including structural, stratigraphic, and combination traps. Among various traps governing conventional accumulations, anticlinal traps are the most typical variety. By contrast, anticlines can hardly function as a trap for the occurrence of continuous and quasi-continuous accumulations.

\section{(4) Controls on hydrocarbon enrichment}

Unlike continuous and quasi-continuous accumulations, all of the essential elements and processes, including source rock, reservoir, seal, trap, migration, accumulation, and preservation, play significant roles in the formation of discontinuous or conventional oil/gas accumulations. Hence, their hydrocarbon enrichment is controlled by multiple factors. Due to good conditions of hydrocarbon migration, such types of oil and gas accumulations are 
often more abundant at higher structural positions (such as uplifts and upper slopes) or relatively shallower strata in a depression or a slope.

\section{Origin and distribution of different types of petroleum systems}

The SPS, TPS, and CPS can coexist in many petroleum basins worldwide. Moreover, they can result from a common hydrocarbon source kitchen in a basin, where they are closely linked and have unique distribution features.

In terms of spatial distribution, both the SPS and the TPS mainly occur in hydrocarbon-generating depressions and slopes, while the CPS tends to have accumulations enriched at the updip parts of a slope and even higher structural positions around a depression or in the shallower formations that are more distant from the effective source rock intervals (Fig. 7). The accumulations in the three PSs often may occur in different stratigraphic intervals more frequently than in a same interval. Generally, their occurrence is vertically sequenced, and the sequence is, from the source rock interval upward or downward, the continuous, quasi-continuous, and discontinuous accumulations, respectively. Usually, quasi-continuous accumulations occur adjacent to the source rock interval, while discontinuous accumulations are more distant. This is because source rock intervals often represent a turning point of sedimentation in the evolution of depositional environments, before and after which are usually transgression cycles and regression cycles, respectively. Thus, the sedimentary sequence is normally graded (coarsening downward) below the source rock interval, while it is reversely graded (coarsening upward) above the source rock interval. As a result, the closer to the source rocks, the finer the deposits become and more likely that tight reservoirs would occur. In contrast, conventional reservoirs are more developed in formations vertically distant from source rocks. Because of the above-mentioned sedimentary cycles, the SPS, TPS, and CPS are frequently formed and coexist in a basin. That should be the primary mechanism for the origin of the three PSs. Thus, it can be predicted that the SPS, TPS, and CPS might coexist in almost all petroliferous basins and can even be derived from the same source kitchen. Indeed, such a phenomenon has been confirmed in many basins worldwide, such as the Ordos Basin, the Songliao Basin, and the Bohai Bay Basin in China, and the Fort Worth Basin (Pollastro 2007), the Piceance Basin (Yurewicz et al. 2008), and the San Juan Basin (Fassett and Boyce 2005) in the USA. In reality, as Forster and Horne (2005) noted, most Rocky Mountain Basins have both conventional and unconventional gas accumulations.
An example is the Ordos Basin, where shale oil, tight oil, and conventional oil accumulations have been found in the Triassic Chang 7 shales (major source rocks of the basin), Chang 9 to Chang $4+5$ tight sandstones, and Chang 3 to Jurassic Yanan Formation good-quality sandstones (Fig. 8). The Chang 7 shales constitute a SPS in which continuous oil accumulations might occur. Above and below the Chang 7 shales, the Chang 9 to Chang $4+5$ tight sandstone pay zones belong to TPSs in which oil accumulations are dominated by quasi-continuous accumulations. The Chang 3 to Yanan Formation oil accumulations are mostly conventional and therefore belong to CPSs. Another example is the Upper Paleozoic natural gas accumulation in the Ordos Basin, where coals in the Benxi, Taiyuan, and Shanxi Formations constitute major source rocks (Zhao et al. 2014). In the coal beds, CBM is widespread mostly as continuous accumulations. The fluvial sandstone reservoirs close to the coal measures are mostly tight reservoirs, and thus quasi-continuous accumulations are predominant. However, some accumulations in the Shiqianfeng Formation may belong to conventional accumulations or discontinuous accumulations due to the good qualities of the reservoirs.

For the SPS, TPS, and CPS derived from a common hydrocarbon source kitchen, the resulting accumulations in source-rock, tight, and conventional reservoirs must be inversely related to each other. Clearly, the proportion of continuous accumulations in the SPS of the total amount of hydrocarbons generated from the source rocks (namely, the retention ratio) is crucial. The higher the retention ratio of hydrocarbons within the source rocks or the lower the hydrocarbon expulsion efficiency, the higher the proportion of hydrocarbon resources in the SPS and the lower the proportion of resources in the TPS and CPS would be. The major factors influencing the retention ratio of hydrocarbons in source rocks include the thickness of effective source rocks, abundance of organic matter, source rock type, and the top and bottom sealing conditions, etc. The thicker the effective source rocks, the higher the organic matter content, and especially, the better the top and bottom sealing conditions, the more abundant the hydrocarbons to be retained in the source rocks. In contrast, if a source rock is too thin and its top and bottom sealing conditions are not good enough, the hydrocarbon expulsion efficiency (reciprocal of the retention ratio) is generally higher and more hydrocarbons generated in the source rock would be expelled and accumulate in non-source rockreservoir intervals or be lost elsewhere. As far as the resource potentials of the TPS and CPS are concerned, they are highly affected by the distribution and quality of tight reservoirs, quality of sealing rocks, and the amount of hydrocarbons expelled from source rocks. It has been found that the better the conditions of tight reservoirs and 


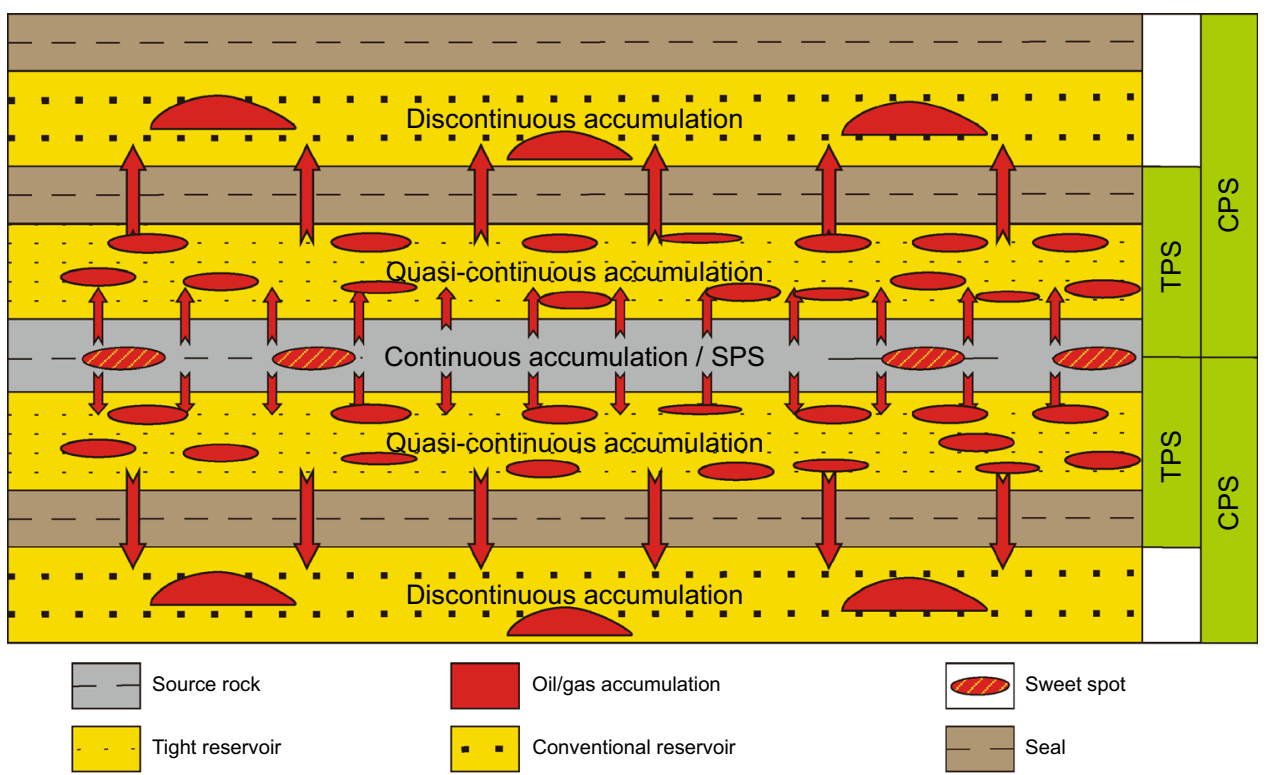

Fig. 7 Schematic illustration of the vertical distribution of the source petroleum system (SPS), tight petroleum system (TPS), and conventional petroleum system (CPS)

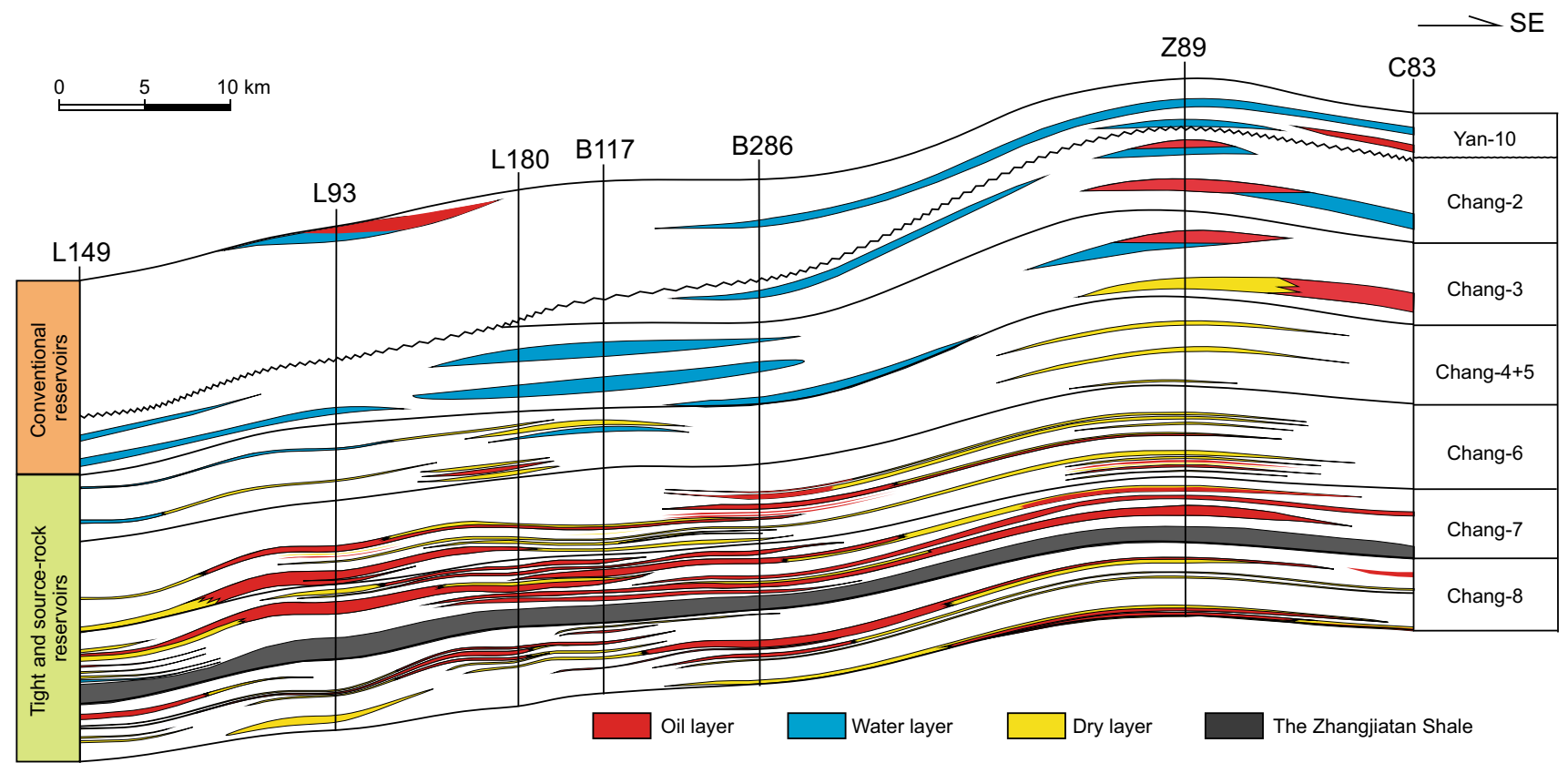

Fig. 8 Cross section showing the distribution of oil accumulations in the Triassic Yanchang Formation of the Ordos Basin. Shale oil is found in the major source rocks (the Zhangjiatan Shale of Chang-7), while closely above and below the Zhangjiatan Shale are abundant

sealing rocks, the more favorable it is for hydrocarbons to accumulate in tight reservoirs. The hydrocarbon resource potential of the TPS is likely to be greater than that of the CPS; otherwise, the CPS would be of greater potential for hydrocarbon resources. This phenomenon can be demonstrated from the distribution of hydrocarbon resource potentials of various accumulations in the Ordos Basin. tight sandstone oil accumulations. However, accumulations are mostly conventional in the Chang $2-3$ and above intervals, which are more distant from the source rock interval

Because both Mesozoic and Upper Paleozoic source rocks are widely distributed in the basin, but their thicknesses are relatively small, the resources retained in the corresponding source rocks, including shale oil/gas and CBM, appear to be less than expected. Nevertheless, tight oil and gas are more plentiful, which is also due to the fact that both tight reservoirs and their cap rocks are well developed in the 
basin. The hydrocarbon resources of conventional accumulations are, therefore, somewhat limited. By corollary, in those basins or regions that are rich in petroleum resources, the potential of unconventional resources would be relatively smaller if their conventional resources are preponderant.

Based on the above discussions, we can conclude that both conventional and unconventional PSs or the CPS, TPS, and SPS can often coexist in petroliferous basins, and are closely linked, but inversely correlated with each other in terms of resource potentials. However, previous studies of the formation and distribution of oil and gas accumulations as well as petroleum exploration are largely focused on conventional PSs and part of unconventional PSs. Consequently, more holistic studies of the entire process and all types of PSs and various petroleum accumulations need to be enhanced to maximize exploration efficiency.

\section{Conclusions}

(1) Petroleum systems can be categorized into three basic types in terms of reservoir qualities as well as the resultant characteristics of hydrocarbon migration and accumulation, namely source-rock petroleum systems (SPS), tight petroleum systems (TPS), and conventional petroleum systems (CPS). In the SPS, continuous hydrocarbon accumulations are predominant, which are typically represented by shale oil/gas and CBM accumulations. The TPS is dominated by quasi-continuous accumulations, but discontinuous accumulations are sometimes significant. In the CPS, however, discontinuous accumulations or conventional trap-controlled accumulations are predominant.

(2) All essential elements and processes, including hydrocarbon generation, charging, sealing, migration, entrapment, and preservation, are indispensable for the CPS, in which hydrocarbon distribution is generally controlled by multiple factors. Moreover, both primary migration and secondary migration are commonly necessary for the CPS, and secondary migration can occur over long distances and is primarily driven by buoyancy. With regard to the TPS, however, migration is dominated by primary and short-distance secondary migration, and the dominant driving force for secondary migration is overpressure instead of buoyancy. The occurrence of petroleum accumulations is primarily controlled by such factors as effective source rocks, reservoirs, and seals. As far as the SPS is concerned, hydrocarbon generation, storage, and sealing are most important factors, whereas migration and trap are of limited importance, as oil and gas accumulate mostly in situ and there is no notable migration, and traps do not function in petroleum accumulation. In the SPS, hydrocarbon enrichment is mainly controlled by source rock attributes, reservoir qualities, and sealing conditions.

(3) In petroliferous basins, conventional and unconventional PSs or the SPS, TPS, and CPS can often coexist, and close relationship is present between them, as observed in many basins across the world, such as the Ordos Basin, the Songliao Basin, and the Bohai Bay Basin in China, and the Fort Worth Basin, the Piceance Basin, and the San Juan Basin in the USA. However, they adversely impact each other with respect to the resource potential. Hence, comprehensive studies of both conventional and unconventional PSs should be strengthened and different strategies ought to be adopted to maximize the exploration efficiency.

Acknowledgements This research was supported by National Science and Technology Major Project of China (Project No. 2016ZX05050, 2011ZX05018001-004) and National Natural Science Foundation Project of China (No. 41402121 and 41502132). We are indebted to those organizations and individuals who provide us with various support.

Open Access This article is distributed under the terms of the Creative Commons Attribution 4.0 International License (http://creative commons.org/licenses/by/4.0/), which permits unrestricted use, distribution, and reproduction in any medium, provided you give appropriate credit to the original author(s) and the source, provide a link to the Creative Commons license, and indicate if changes were made.

\section{References}

Ayers WB Jr. Coalbed gas systems, resources, and production and a review of contrasting cases from the San Juan and Powder River Basins. AAPG Bull. 2002;86:1853-90.

Bian CS, Wang HJ, Wang ZC, Xu ZH. Exploration status and potential evaluation of tight gas in Sichuan Basin. China Eng Sci. 2012;14:74-80 (in Chinese).

Bowker KA. Barnett shale gas production, Fort Worth Basin: issues and discussion. AAPG Bull. 2007;91:523-33.

Bustin AMM, Bustin RM. Importance of rock properties on the producibility of gas shales. Int J Coal Geol. 2012;103:132-47.

Camp WK. Basin-centered gas or subtle conventional traps? In: Cumella SP, Shanley KW, Camp WK, editors. Understanding exploring, and developing tight-gas sands-2005 Vail Hedberg Conference, vol. 3. Tulsa: AAPG Hedberg Series; 2008. p. 49-61.

Cant D. "Unconventional" hydrocarbon accumulations occur in conventional traps. CSPG CSEG CWLS Conv. 2011;2011:1-2.

Cao Q, Zhao JZ, Fu JH, et al. Gas source conditions of quasicontinuous accumulation of the Upper Paleozoic in Ordos Basin. Oil Gas Geol. 2013a;34:584-91 (in Chinese). 
Cao Q, Zhao JZ, Liu XS, et al. Determination of physical property limits for the gas accumulation in tight sandstone reservoirs in the eastern Ordos Basin. Acta Pet Sin. 2013b;34:1040-8 (in Chinese).

Chalmers GR, Bustin RM, Power IM. Characterization of gas shale pore systems by porosimetry, pycnometry, surface area, and field emission scanning electron microscopy/transmission electron microscopy image analyses: examples from the Barnett, Woodford, Haynesville, Marcellus, and Doig units. AAPG Bull. 2012;96:1099-119.

Cumella SP, Shanley KW, Camp WK. Introduction. In: Cumella SP, Shanley KW, Camp WK, editors. Understanding, exploring, and developing tight-gas sands-2005 Vail Hedberg Conference, vol. 3. Tulsa: AAPG Hedberg Series; 2008. p. 1-4.

Curtis JB. Fractured shale-gas systems. AAPG Bull. 2002;86:1921-38.

Curtis ME, Cardott B, Sondergeld C, Rai CS. Development of organic porosity in the Woodford Shale with increasing thermal maturity. Int J Coal Geol. 2012;103:26-31.

Dai JX, Ni YY, Wu XQ. Tight gas in China and its significance in exploration and exploitation. Pet Explor Dev. 2012;39:277-84.

Dai JX, Ni YY, Gong DY, et al. Geochemical characteristics of gases from the largest tight sand gas field (Sulige) and shale gas field (Fuling) in China. Mar Pet Geol. 2017;79:426-38.

Dai JX, Zou CN, Dong DZ, et al. Geochemical characteristics of marine and terrestrial shale gas in China. Mar Pet Geol. 2016;76:444-63.

Demaison G, Huizinga BJ. Genetic classification of petroleum systems. AAPG Bull. 1991;75:1626-43.

De Silva PNK, Simons SJR, Stevens P, et al. A comparison of North American shale plays with emerging non-marine shale plays in Australia. Mar Pet Geol. 2015;67:16-29.

Dong DZ, Gao SK, Huang JL, et al. A discussion on the shale gas exploration and development prospect in the Sichuan Basin. Nat Gas Ind. 2014;12:1-15 (in Chinese).

Dong DZ, Wang YM, Huang XN, et al. Discussion about geological characteristics, resource evaluation methods and its key parameters of shale gas in China. Nat Gas Geosci. 2016;27:1583-601 (in Chinese).

Dubiel RF, Pitman JK, Pearson ON, et al. Assessment of undiscovered oil and gas resources in conventional and continuous petroleum systems in the upper Cretaceous Eagle Ford Group, U.S. Gulf Coast region, 2011. 2012. https://pubs.usgs.gov/fs/ 2012/3003/FS12-3003.pdf.

EIA. Review of emerging resources: U.S. shale gas and shale oil plays. https://www.eia.gov/analysis/studies/usshalegas/pdf/ussha leplays.pdf 2011; p. 82.

Er C, Zhao JZ, Bai YB, et al. Reservoir characteristics of the organicrich shales of the Triassic Yanchang Formation in Ordos Basin. Oil Gas Geol. 2013;34:708-16 (in Chinese).

Fassett JE, Boyce BC. Fractured-sandstone gas reservoirs, San Juan Basin, New Mexico and Colorado: stratigraphic traps, not basincentered gas deposits - with an overview of Fruitland Formation coal-bed methane. In: Bishop MG, Cumella SP, Robinson JW, Silverman MR, editors. Gas in low permeability reservoirs of the Rocky Mountain Region. Rocky Mountain Association of Geologists 2005 Guidebook CD 2005;109-85.

Forster JR, Horne JC. The interpretation of fluids and pressures in determining conventional and unconventional gas resources in the Rocky Mountain Region. In: Bishop MG, Cumella SP, Robinson JW, Silverman MR, editors. Gas in low permeability reservoirs of the Rocky Mountain Region. Rocky Mountain Association of Geologists 2005 Guidebook CD 2005; 187-213.

Fu JH, Wei XX, Ren JF. Distribution and genesis of large-scale Upper Palaeozoic lithologic gas reservoirs on Yi-Shaan slope. Pet Explor Dev. 2008;35:664-7.
Gaswirth SB. Assessment of continuous oil resources in the Wolfcamp shale of the Midland Basin, Permian Basin Province, Texas, 2016. U.S. Geological Survey Open File-Report 2017; 1013: 14 https://doi.org/10.3133/ofr20171013.

Gaswirth SB, Marra KR, Cook TA, et al. Assessment of undiscovered oil resources in the Bakken and Three Forks Formations, Williston Basin Province, Montana, North Dakota, and South Dakota 2013. https://pubs.usgs.gov/fs/2013/3013/fs2013-3013. pdf.

Ground Water Protection Council. Modern shale gas development in the United States: a primer. Oklahoma City: Ground water protection; 2009. p. 116.

Guo TL. Evaluation of highly thermally mature shale-gas reservoirs in complex structural parts of the Sichuan Basin. J Ear Sci. 2013;24:863-73.

Halbouty MT. Giant oil and gas fields of the decade 1990-1999. AAPG Memoir. 2003;78:275-332.

Hanson WB, Vega V, Cox D. Structural geology, seismic imaging, and genesis of the giant Jonah gas field, Wyoming, U.S.A. In: Robinson JR, Shanley KW, editors. Jonah field: case study of a giant tight-gas fluvial reservoir,vol. 52. Tulsa: AAPG Studies in Geology; 2004. p. 61-92.

Hood KC, Yurewicz DA. Assessing the Mesaverde basin-centered gas play, Piceance Basin, Colorado. In: Cumella SP, Shanley KW, Camp WK, editors. Understanding, exploring, and developing tight-gas sands-2005 Vail Hedberg Conference, vol. 3. Tulsa: AAPG Hedberg Series; 2008. p. 87-104.

Hou QJ, Wei ZS, Zhao ZY, et al. Deep basin reservoir in Songliao Basin. Pet Explor Dev. 2006;32:406-11 (in Chinese).

Jarvie DM. Unconventional oil petroleum systems: shales and shale hybrids. AAPG International \& Conference Exchange, Calgary, Alberta, Canada, September 12-15, 2010. Search and Discovery Article \#80131 2011; p. 1-21.

Jarvie DM. Shale resource systems for oil and gas: Part 1—shale-gas resource systems. In: Breyer JA, editor. Shale reservoirs-giant resources for the 21st century, vol. 97. Tulsa: AAPG Memoir; 2012. p. 69-87.

Jarvie DM, Hill RJ, Ruble TE, et al. Unconventional shale-gas systems: the Mississippian Barnett Shale of north-central Texas as one model for thermogenic shale-gas assessment. AAPG Bull. 2007;91:475-99.

Jiang FJ, Chen D, Wang ZF, et al. Pore characteristic analysis of a lacustrine shale: a case study in the Ordos Basin, NW China. Mar Pet Geol. 2016;73:554-71.

Ju YW, Wang GC, Bu HL, et al. China organic-rich shale geologic features and special shale gas production issues. J Rock Mech Geot Eng. 2014;6:196-207.

Katz BJ, Everett MA. An overview of pre-Devonian petroleum systems-unique characteristics and elevated risks. Mar Pet Geol. 2016;73:492-516.

Law BE. Basin-centered gas systems. AAPG Bull. 2002;86:1891-919.

Li J. Analysis on mineral components and frangibility of shales in Dongying depression. Acta Sed Sin. 2013;31:616-20 (in Chinese).

Li J, Wei GQ, Xie ZY, et al. Accumulation mechanism and main controlling factors of large tight sandstones gas fields in China: case study on Ordos Basin and Sichuan Basin. Acta Pet Sin. 2013a;34(s1):14-28 (in Chinese).

Li Z, Jiang ZX, Pang XQ, et al. Genetic types of the tight sandstone gas reservoirs in the Kuqa Depression, Tarim Basin, NW China. Ear Sci J China Univ Geosci. 2013b;38:156-64 (in Chinese).

$\mathrm{Li} \mathrm{ZH,} \mathrm{Li} \mathrm{SL,} \mathrm{Yu} \mathrm{XH,} \mathrm{et} \mathrm{al.} \mathrm{Coalbed} \mathrm{methane} \mathrm{enrichment} \mathrm{regularities}$ and controlling factors in Bowen-Surat Basin, Australia. Coal Geol Explor. 2014;42:29-33 (in Chinese). 
Lin $\mathrm{XY}, \mathrm{Su} \mathrm{XB}$. Reservoiring mechanism of coalbed methane in southern Qinshui Basin. Nat Gas Ind. 2007;27:8-11 (in Chinese).

Liu CL, Wang ZL, Guo ZQ, et al. Enrichment and distribution of shale oil in the Cretaceous Qingshankou Formation, Songliao Basin, Northeast China. Mar Pet Geol. 2017;86:751-70.

Loucks RG, Reed RM, Ruppel SC, et al. Morphology, genesis, and distribution of nanometer -scale pores in siliceous mudstones of the Mississippian Barnett Shale. J Sed Res. 2009;79:848-61.

Lü ZX, Ye SJ, Yang X, et al. Quantification and timing of porosity evolution in tight sand gas reservoirs: an example from the Middle Jurassic Shaximiao Formation, western Sichuan, China. Pet Sci. 2015;12:207-17.

Luo WJ, Peng JA, Du J, et al. Diagenesis and porosity evolution of tight sand reservoirs in the 2nd member of Xujiahe Formation, western Sichuan Depression: an example from Dayi region. Oil Gas Geol. 2012;33:287-95 (in Chinese).

Magoon LB. Identified petroleum systems within the United States1990. In: Magoon LB, editors. The petroleum system — status of research and methods, 1990. USGS Bull. 1989; 1912: 2-9.

Magoon LB, Dow WG. The petroleum system. In: Magoon LB, Dow WG, editors. The petroleum system-from source to trap, vol. 60. Tulsa: AAPG Memoir ; 1994. p. 3-24.

Magoon LB, Schmoker, JW. The total petroleum system-the natural fluid network that constrains the assessment unit. In: U.S. Geological Survey World Energy Assessment Team, editors. U.S. Geological Survey world petroleum assessment 2000description and results. U.S. Geological Survey Digital Data Series DDS-60, version 1.0, CD-ROM, Disk 1, Chapter PS 2000; $31 \mathrm{pp}$.

Marra KR, Charpentier RR, Schenk CJ, et al. Assessment of undiscovered shale gas and shale oil resources in the Mississippian Barnett Shale, Bend Arch-Fort Worth Basin Province, north-central Texas. U.S. Geological Survey Fact Sheet. 2015;3078:2. https://doi.org/10.3133/fs20153078.

Mastalerz M, Schimmelmann A, Drobniak A, et al. Porosity of Devonian and Mississippian New Albany Shale across a maturation gradient: insights from organic petrology, gas adsorption, and mercury intrusion. AAPG Bull. 2013;97:1621-43.

Masters JA. Deep basin gas trap, western Canada. AAPG Bull. 1979;63:152-81.

Masters JA. Lower cretaceous oil and gas in western Canada. In: Masters JA, editors. Elmworth, case study of a deep basin gas field, vol. 38. Tulsa: AAPG Memoir; 1984. p. 1-34.

McCullagh T, Hart B. Stratigraphic controls on production from a basin-centered gas system: lower Cretaceous Cadotte Member, Deep Basin, Alberta, Canada. AAPG Bull. 2010;94:293-315.

Milliken KL, Rudnicki M, Awwiller DN, et al. Organic matter-hosted pore system, Marcellus Formation (Devonian), Pennsylvania. AAPG Bull. 2013;97:177-200.

Passey QR, Bohacs KM, Esch WL, et al. From oil-prone source rock to gas producing reservoir-geologic and petrophysical characterization of unconventional shale-gas reservoirs. In: CPS/SPE International Oil \& Gas Conference and Exhibition. Beijing, China, June 8 -10. SPE 2010; 131350.

Paxton ST, Pitman JK, Kinney SA, et al. Assessment of undiscovered oil and gas resources in the Haynesville Formation, U.S. Gulf Coast, 2016. U.S. Geological Survey Fact Sheet 2017; 3016: 2. https://doi.org/10.3133/fs20173016.

Pepper AS. Estimating the petroleum expulsion behavior of source rocks: a novel quantitative approach. In: England WA, Fleet AL, editors. Petroleum migration, vol. 59. London: Geological Society (London) Special Publications; 1992. p. 9-31.

Pollastro RM. Total petroleum system assessment of undiscovered resources in the giant Barnett Shale continuous (unconventional) gas accumulation, Fort Worth Basin, Texas. AAPG Bull. 2007;91:551-78.

Rezaee R, Rothwell M. Gas shale: global significance distribution and challenges. In: Rezaee R, editor. Fundamentals of gas shale reservoirs. London: Wiley; 2015. p. 1-19.

Rodriguez ND, Philp RP. Geochemical characterization of gases from the Mississippian Barnett Shale, Fort Worth Basin, Texas. AAPG Bull. 2010;94:1641-56.

Ross DJK, Bustin RM. The importance of shale composition and pore structure upon gas storage potential of shale gas reservoirs. Mar Pet Geol. 2009;26:916-27.

Schmoker JW. Method for assessing continuous-type (unconventional) hydrocarbon accumulations (CD-ROM). In: Gautier DL, Dolton GL, Takahashi KT, Varnes KL, editors. 1995 National assessment of United States oil and gas resources-results, methodology, and supporting data. U. S. Geological Survey Digital Data Series 1995; 30.

Schmoker JW. Resource-assessment perspectives for unconventional gas systems. AAPG Bull. 2002;86:1993-9.

Shanley KW, Cluff RM, Robinson JW. Factors controlling prolific gas production from low-permeability sandstone reservoirs. AAPG Bull. 2004;88:1083-121.

Slatt RM. Important geological properties of unconventional resource shales. Cent Eur J Geol. 2011;3:435-48.

Song Y, Li Z, Jiang L, et al. The concept and the accumulation characteristics of unconventional hydrocarbon resources. Pet Sci. 2015; 12:563-72.

Sun HQ. Exploration practice and cognitions of shale oil in Jiyang depression. China Pet Explor. 2017;4:1-14 (in Chinese).

Wang GT, Li YL, He DB, et al. Characteristics of "subsequent" tight gas accumulation: a case from Badaowan Formation of Lower Jurassic in Baka Gas Field, Tuha Basin. Geol Sci Tech Inf. 2014;33:118-25 (in Chinese).

Wang XK, Sheng J. Gas sorption and non-Darcy flow in shale reservoirs. Pet Sci. 2017;14:746-54.

Wei GQ, Li J, Xie ZY, et al. Reservoir geology and exploration theories of large gas fields in China. Acta Pet Sin. 2013;34(s1):1-13 (in Chinese).

Wilson MJ, Shaldybin MV, Clay Wilson L. mineralogy and unconventional hydrocarbon shale reservoirs in the USA. I. Occurrence and interpretation of mixed-layer R3 ordered illite/smectite. Earth-Sci Rev. 2016;158:31-50.

Yang KM, Pang XQ. Mechanism of tight sandstone gas accumulation and methods of prediction: a case study in the western Sichuan Basin. Beijing: Science Press; 2012. p. 1-312 (in Chinese).

Yurewicz DA, Bohacs KM, Kendall J, et al. Controls on gas and water distribution, Mesaverde basin-centered gas play, Piceance Basin, Colorado. In: Cumella SP, Shanley KW, Camp WK, editors. Understanding, exploring, and developing tight-gas sands-2005 Vail Hedberg conference, vol. 3. Tulsa: AAPG Hedberg Series 2008. p. 105-36.

Zagorski WA, Wrightstone GR, Bowman DC. The Appalachian Basin Marcellus gas play: its history of development, geologic controls on production, and future potential as a world-class reservoir. In: Breyer JA , editor. Shale reservoirs-giant resources for the 21st century, vol. 97. AAPG Memoir; 2012. p. 172-200.

Zhang WZ, Yang H, Li JF, et al. Leading effect of high-class source rock of Chang 7 in Ordos Basin on enrichment of low permeability oil-gas accumulation-hydrocarbon generation and expulsion mechanism. Pet Explor Dev. 2006;33:289-93 (in Chinese).

Zhang XS, Wang HJ, Ma F, et al. Classification and characteristics of tight oil plays. Pet Sci. 2016;13:18-33.

Zhang ZS. Overview of giant gas fields around the world. Beijing: Petroleum Press. 1990. 1-286 (in Chinese). 
Zhao JZ, Al-aasm IS. New insights into petroleum migrationaccumulation dynamic systems and their division within petroleum systems. J Ear Sci. 2012;23:744-56.

Zhao JZ, Cao Q, Bai YB, et al. Petroleum accumulation from continuous to discontinuous: concept, classification and distribution. Acta Pet Sin. 2016a;37:145-59 (in Chinese).

Zhao JZ, Fu JH, Yao JL, et al. Quasi-continuous accumulation model of large tight sandstone gas field in Ordos Basin. Acta Pet Sin. 2012a;32(s1):37-52 (in Chinese).

Zhao JZ, Li J, Cao Q, et al. Hydrocarbon accumulation patterns of large tight oil and gas fields. Oil Gas Geol. 2013;34:573-83 (in Chinese).

Zhao JZ, Wang R, Er C. Adsorption characteristics of Chang 7 shales from Triassic Yanchang Formation and the controlling factors, the Ordos Basin. Ear. Sci. Fron. 2016b;23:146-53 (in Chinese).

Zhao JZ, Zhang WZ, Li J, et al. Genesis of tight sand gas in the Ordos Basin, China. Org Geochem. 2014;74:76-84.

Zhao WZ, Wang ZC, Zhu YX, et al. Forming mechanism of lowefficiency gas reservoir in Sulige gas field of Ordos Basin. Acta Pet Sin. 2005;26:5-9 (in Chinese).
Zhao WZ, He DF. Concept and its significance of composite petroleum system in China. Pet Explor. 2000;5:1-11 (in Chinese).

Zhao XZ, Zhou LH, Pu XG, et al. Geological characteristics of shale rock system and shale oil breakthrough in a lacustrine basin: a case study from the Paleogene 1st sub-member of Kong 2 Member in Cangdong sag, Bohai Bay Basin, China. Pet Explor Dev. 2018;45:377-88.

Zhao ZZ, Du JH. Tight oil and gas. Beijing: Petroleum Press, 2012b; p. 199 (in Chinese).

Zhu RK, Zou CN, Zhang N, et al. Diagenetic fluids evolution and genetic mechanism of tight sandstone gas reservoirs in Upper Triassic Xujiahe Formation in Sichuan Basin, China. Sci China Ear Sci. 2008;51:1340-53.

Zou CN, Zhai GM, Zhang GY, et al. Formation, distribution, potential and prediction of global conventional and unconventional hydrocarbon resources. Pet Explor Dev. 2015;42:14-28.

Zou CN, Zhao Q, Dong DZ, et al. Geological characteristics, main challenges and future prospect of shale gas. Nat Gas Geosci. 2017;12:1781-96 (in Chinese). 